\title{
Hydrothermal synthesis of manganese phosphate/graphene foam composite for electrochemical supercapacitor applications
}

\author{
Abdulmajid Abdallah Mirghni, Moshawe Jack Madito, Tshifhiwa Moureen Masikhwa, Kabir \\ O. Oyedotun, Abdulhakeem Bello and Ncholu Manyala* \\ Department of Physics, Institute of Applied Materials, SARCHI Chair in Carbon Technology and Materials, \\ University of Pretoria, Pretoria 0028, South Africa \\ *Corresponding author’s email: ncholu.manyala@up.ac.za, Tel.: +(27)12 420 3549;
}

Fax: +(27)12 4202516

\begin{abstract}
Manganese phosphate $\left(\mathrm{Mn}_{3}\left(\mathrm{PO}_{4}\right)_{2}\right.$ hexagonal micro-rods and $\left(\mathrm{Mn}_{3}\left(\mathrm{PO}_{4}\right)_{2}\right.$ with different graphene foam (GF) mass loading up to $150 \mathrm{mg}$ were prepared by facile hydrothermal method. The characterization of the as-prepared samples proved the successful synthesis of $\mathrm{Mn}_{3}\left(\mathrm{PO}_{4}\right)_{2}$ hexagonal micro-rods and $\mathrm{Mn}_{3}\left(\mathrm{PO}_{4}\right)_{2} / \mathrm{GF}$ composites. It was observed that the specific capacitance of $\mathrm{Mn}_{3}\left(\mathrm{PO}_{4}\right)_{2} / \mathrm{GF}$ composites with different GF mass loading increases with mass loading up to $100 \mathrm{mg}$, and then decreases with increasing mass loading up to $150 \mathrm{mg}$. The specific capacitance of $\mathrm{Mn}_{3}\left(\mathrm{PO}_{4}\right)_{2} / 100 \mathrm{mg} \mathrm{GF}$ electrode was calculated to be $270 \mathrm{~F} \mathrm{~g}^{-1}$ as compared to $41 \mathrm{~F} \mathrm{~g}^{-1}$ of the pristine sample at a current density of $0.5 \mathrm{~A} \mathrm{~g}^{-1}$ in a three-electrode cell configuration using $6 \mathrm{M} \mathrm{KOH}$. Furthermore, the electrochemical performance of the $\mathrm{Mn}_{3}\left(\mathrm{PO}_{4}\right)_{2} / 100 \mathrm{mg} \mathrm{GF}$ electrode was evaluated in a two-electrode asymmetric cell device where $\mathrm{Mn}_{3}\left(\mathrm{PO}_{4}\right)_{2} / 100 \mathrm{mg}$ GF electrode was used as a positive electrode and activated carbon (AC) from coconut shell as a negative electrode. $\mathrm{AC} / / \mathrm{Mn}_{3}\left(\mathrm{PO}_{4}\right)_{2} / 100 \mathrm{mg}$ GF asymmetric cell device was tested within the potential window of $0.0-1.4 \mathrm{~V}$, and showed excellent cycling stability with $96 \%$ capacitance retention over 10000 galvanostatic charge-discharge cycles at a current density of $2 \mathrm{~A} \mathrm{~g}^{-1}$.
\end{abstract}




\section{GRAPHICAL ABSTRACT}
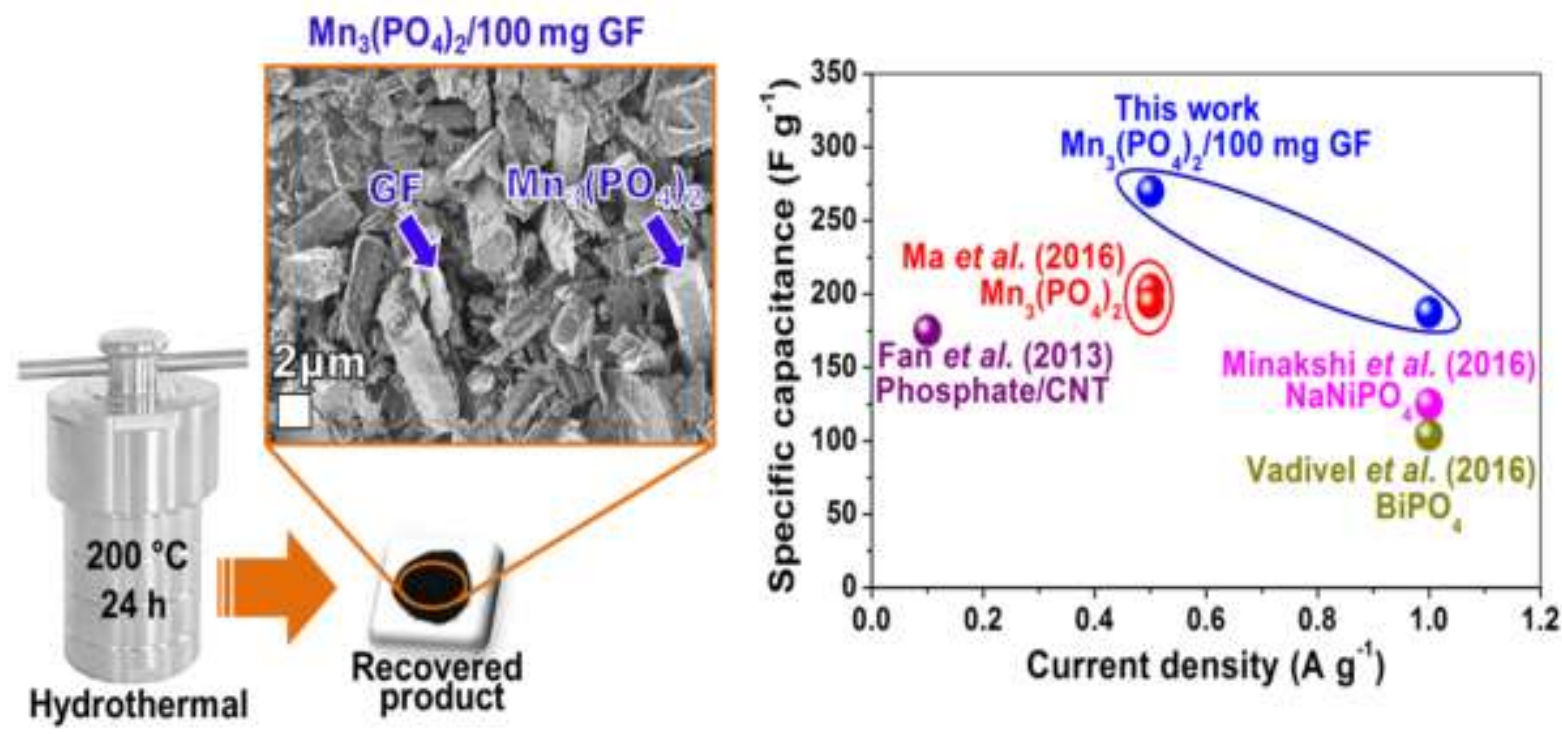

KEYWORDS: Manganese phosphate, Activated carbon, Graphene foam, Hydrothermal method, Asymmetric supercapacitor, Energy storage.

\section{INTRODUCTION}

Electrochemical capacitors or supercapacitors (SCs), because of their high power density, low fabrication cost, and high stability have attracted a lot of research attention as result of increasing needs of energy storage devices with different properties [1-4]. SCs are widely used in numerous areas as power supply, hybrid-electric vehicles (HEVs) and electronic devices. Generally, based on charge-discharge mechanism, SCs can be categorized into two types of capacitors: electrochemical double-layer capacitors (EDLC) and pseudocapacitors [5]. EDLC consist of high specific surface area materials, like carbon nano-materials and store energy in the electrical double layers. Pseudocapacitors materials show several oxidation states and store energy not only in electric double layers, but also in reversible redox reactions occurring on or near the electrode surface, like conductive polymers and transition metal oxides/hydroxides [5-8]. Therefore, in terms of comparison, pseudocapacitor exhibits better capacitive behavior with high specific capacitance [9].

Furthermore, metal oxides including $\mathrm{RuO}_{2}, \mathrm{MnO}_{2}, \mathrm{NiO}$, and $\mathrm{Co}_{3} \mathrm{O}_{4}$ exhibit high specific capacitance $[10,11]$. Thus metal oxide/carbon composite which can affect the electrochemical 
performance of supercapacitors have been intensively investigated as electrode materials for supercapacitors [12-14]. Manganese oxide $\left(\mathrm{MnO}_{2}\right)$, which is promising pseudocapacitive electrode material for supercapacitors has become an interesting electrode material due to its excellent theoretical capacitance $\left(1370 \mathrm{Fg}^{-1}\right)$, low-cost and is eco-friendly cathode material $[15,16]$. However, in supercapacitor applications, it is hard to reach this theoretical value because of poor electrical conductivity $\left(10^{-5}-10^{-6} \mathrm{~S} \mathrm{~cm}^{-1}\right)$ and slow ion transfer rate which limit the specific capacitance and charge/discharge ability of the electrode [17-21]. On the other hand, metal phosphates or manganese phosphates have been extensively explored in high-performance solar cells, lithium batteries and rarely in SCs [22-24]. In addition, cobalt phosphate has been used as a bright positive electrode for rechargeable ion batteries, catalysis, ion exchangers and magnetic materials due to layers of interconnected $\mathrm{Co}_{x}$ and $\mathrm{PO}_{4}$ and outstanding electronic or magnetic properties [25,26]. Li et al synthesized amorphous colloidal sphere structure of metal phosphate and they have observed that this structure can significantly enrich the pool of available materials in the fields of catalysis and lithium-ion battery electrodes [22]. W. Massa et al reported a new orthophosphate $\mathrm{Mn}_{3}\left(\mathrm{PO}_{4}\right)_{2}$ where $\left(\mathrm{MnO}_{5}\right)$ polyhedra and $\left(\mathrm{MnO}_{6}\right)$ octahedra share common edges to form chains alternating along the (110) and (110) directions [27]. Ma et al studied electrochemical performance of manganese phosphate with nanosheets structure in a three-electrode cell configuration, but using alkaline and neutral electrolytes and they reported a high specific capacitance of 203 $\mathrm{Fg}^{-1}$ and $194 \mathrm{Fg}^{-1}$ at a current density of $0.5 \mathrm{Ag}^{-1}$ using $1 \mathrm{M} \mathrm{Na}_{2} \mathrm{SO}_{4}$ and $2 \mathrm{M} \mathrm{KOH}$ electrolytes respectively [28]. Generally, synthesis of manganese phosphates with different morphologies always remains very attractive due to their unique advantages, such as abundant active sites for reactions with fast interfacial transport of charge carriers by decreasing the diffusion path length through the structure, and also because phosphate has strong P-O covalent bonds which makes $\mathrm{Mn}_{3}\left(\mathrm{PO}_{4}\right)_{2}$ structure chemically very stable. In supercapacitor applications, a short diffusion path length of charge carriers and chemically stable structure of the electrode are very important. Furthermore, despite previously published results, the studies concerning manganese phosphates electrodes for supercapacitor applications are lacking in the literature.

Herein, we report a facile hydrothermal route to synthesis $\mathrm{Mn}_{3}\left(\mathrm{PO}_{4}\right)_{2}$ hexagonal micro-rods using manganese acetate $\left(\mathrm{C}_{4} \mathrm{H}_{6} \mathrm{MnO}_{4}\right)$ and ammonium phosphate $\left(\mathrm{N}_{2} \mathrm{H}_{9} \mathrm{PO}_{4}\right)$ as precursors. In addition, $\mathrm{Mn}_{3}\left(\mathrm{PO}_{4}\right)_{2}$ /graphene foam (GF) composites with different GF mass loading were also synthesized by a hydrothermal process to improve on the surface electrical conductivity 
of $\mathrm{Mn}_{3}\left(\mathrm{PO}_{4}\right)_{2}$ to enhance the electrochemical performance of the electrode. Our choice of the hydrothermal technique is due to the fact that it facilitates the fabrication of most complex material(s) with a desired physio-chemical properties, and it also offers several advantages over the other conventional processes like energy saving, simplicity, cost effectiveness, high purity and crystalline materials, pollution free (since the reaction is carried out in a closed system), higher rate of reaction, better morphology control, and lower temperature of operation in the presence of an appropriate solvent, etc. The electrochemical performance of as-prepared $\mathrm{Mn}_{3}\left(\mathrm{PO}_{4}\right)_{2}$ hexagonal micro-rods and $\mathrm{Mn}_{3}\left(\mathrm{PO}_{4}\right)_{2} / \mathrm{GF}$ composites was evaluated in a three-electrode cell configuration using $6 \mathrm{M} \mathrm{KOH}$. The specific capacitance of $\mathrm{Mn}_{3}\left(\mathrm{PO}_{4}\right)_{2}$ electrode was obtained as $41 \mathrm{~F} \mathrm{~g}^{-1}$ and that of $\mathrm{Mn}_{3}\left(\mathrm{PO}_{4}\right)_{2} / 100 \mathrm{mg}$ GF electrode which showed the highest value as $270 \mathrm{Fg}^{-1}$ at a current density of $0.5 \mathrm{Ag} \mathrm{g}^{-1}$. The electrochemical performance of the $\mathrm{Mn}_{3}\left(\mathrm{PO}_{4}\right)_{2} / 100 \mathrm{mg}$ GF electrode was also evaluated in two-electrode asymmetric cell device where $\mathrm{Mn}_{3}\left(\mathrm{PO}_{4}\right)_{2} / 100 \mathrm{mg}$ GF electrode served as a positive electrode and activated carbon (AC) from coconut shell as a negative electrode. $\mathrm{AC} / / \mathrm{Mn}_{3}\left(\mathrm{PO}_{4}\right)_{2} / 100 \mathrm{mg}$ GF asymmetric cell device showed excellent cycling stability with 96\% capacitance retention over 10000 galvanostatic charge-discharge cycles at a current density of $2 \mathrm{~A} \mathrm{~g}^{-1}$.

\section{EXPERIMENTAL}

\subsection{Materials}

Manganese acetate $\left(\mathrm{C}_{4} \mathrm{H}_{6} \mathrm{MnO}_{4}\right.$, purity $\left.\geq 99 \%\right)$ and ammonium phosphate $\left(\mathrm{N}_{2} \mathrm{H}_{9} \mathrm{PO}_{4}\right.$, purity $\geq 98 \%$ ), were purchased from Sigma-Aldrich. Polycrystalline Ni foam (3D scaffold template with an areal density of $420 \mathrm{~g} \mathrm{~m}^{2}$ and in thickness of $1.6 \mathrm{~mm}$ was purchased from Alantum (Munich, Germany). Potassium hydroxide $(\mathrm{KOH}$, min 85\%) was purchased from Merck (South Africa).

\subsection{Synthesis of $\mathrm{Mn}_{3}\left(\mathrm{PO}_{4}\right)_{2}$ using hydrothermal method}

In the synthesis of manganese phosphate, all the chemical reagents were used without any further purification. Scheme 1 shows the schematic view of the procedure used in the preparation of manganese phosphate. An analytical grade of $\mathrm{C}_{4} \mathrm{H}_{6} \mathrm{MnO}_{4}$ and $\mathrm{N}_{2} \mathrm{H}_{9} \mathrm{PO}_{4}$ with the required stoichiometric amount and the weight ratio of 3:1 were used. Initially, $60 \mathrm{mM}$ $\mathrm{C}_{4} \mathrm{H}_{6} \mathrm{MnO}_{4}$ and $20 \mathrm{mM} \mathrm{N} \mathrm{H}_{9} \mathrm{PO}_{4}$ were dissolved separately each in $50 \mathrm{~mL}$ deionized water, 
as demonstrated in scheme 1. Then the solution of $\mathrm{C}_{4} \mathrm{H}_{6} \mathrm{MnO}_{4}$ was added dropwise into $\mathrm{N}_{2} \mathrm{H}_{9} \mathrm{PO}_{4}$ solution and stirred for $18 \mathrm{~h}$. After stirring, the solution was transferred into a sealed, Teflon-lined, stainless-steel autoclave and kept at a temperature of $200{ }^{\circ} \mathrm{C}$ for $24 \mathrm{~h}$ and then cooled to room temperature. Finally, the recovered product was filtered and washed several times with deionized water and dried overnight at $60{ }^{\circ} \mathrm{C}$ to obtain $\mathrm{Mn}_{3}\left(\mathrm{PO}_{4}\right)_{2}$ microrods as shown by micrograph image in the last step of scheme 1 .
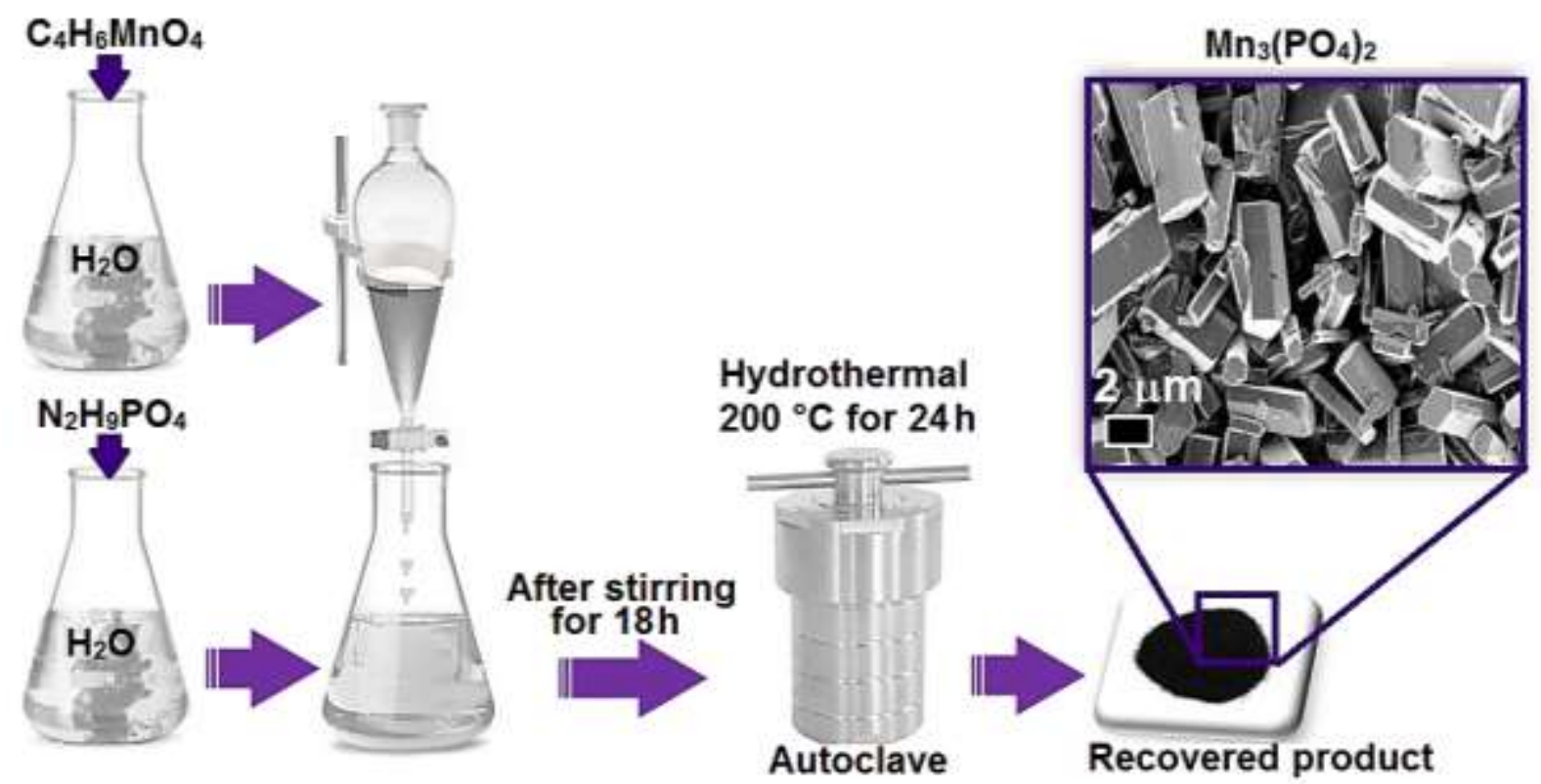

Scheme 1. Preparation procedure of manganese phosphate, $\mathrm{Mn}_{3}\left(\mathrm{PO}_{4}\right)_{2}$ micro-rods.

\subsection{Synthesis of GF using chemical vapor deposition}

In a typical procedure for graphene growth using chemical vapor deposition (CVD) involved polycrystalline Ni foam (3D scaffold template) which was placed at a centre of a CVD quartz tube. Before graphene growth, the nickel foam was annealed at $1000{ }^{\circ} \mathrm{C}$ under a mixture of argon (Ar) and hydrogen $\left(\mathrm{H}_{2}\right)$ gasses for $60 \mathrm{~min}$. Subsequently, methane $\left(\mathrm{CH}_{4}\right)$ gas (acting as a carbon source) was introduced into the reaction chamber at $1000{ }^{\circ} \mathrm{C}$ for $10 \mathrm{~min}$ and the flow rates of the gasses $\mathrm{Ar}: \mathrm{H}_{2}: \mathrm{CH}_{4}$ were 300:200:10 sccm respectively. After graphene growth, the samples were rapidly cooled by pushing the quartz tube to a cooler region of the furnace. In order to get the GF, the samples were further dipped in $3.0 \mathrm{M} \mathrm{HCl}$ at $80{ }^{\circ} \mathrm{C}$ to ensure complete etching of the nickel supporting structure. After complete etching of the nickel template, the recovered GF was washed several times with deionized water and dried at $60{ }^{\circ} \mathrm{C}$. 


\subsection{Synthesis of $\mathrm{Mn}_{3}\left(\mathrm{PO}_{4}\right)_{2} / \mathrm{GF}$ composites using hydrothermal method}

The $\mathrm{Mn}_{3}\left(\mathrm{PO}_{4}\right)_{2} / \mathrm{GF}$ composite was prepared using a hydrothermal technique. Typically, $50 \mathrm{mg}$ of the as-prepared GF was dispersed in $100 \mathrm{~mL}$ of deionized water by ultra-sonication for $18 \mathrm{~h}$ at room temperature. Then $1.014 \mathrm{~g}$ of $\mathrm{C}_{4} \mathrm{H}_{6} \mathrm{MnO}_{4}$ and $0.264 \mathrm{~g}$ of $\mathrm{N}_{2} \mathrm{H}_{9} \mathrm{PO}_{4}$ were added to the sonicated GF solution and the entire mixture was further stirred for $18 \mathrm{~h}$. Thereafter, the mixture was transferred into a sealed, Teflon-lined, stainless-steel autoclave and kept at a temperature of $200{ }^{\circ} \mathrm{C}$ for $24 \mathrm{~h}$. After cooling to room temperature, the recovered product of $\mathrm{Mn}_{3}\left(\mathrm{PO}_{4}\right)_{2} / 50 \mathrm{mg}$ GF composite was washed with deionized water and dried overnight at $60{ }^{\circ} \mathrm{C}$. This procedure was repeated for the synthesis of $\mathrm{Mn}_{3}\left(\mathrm{PO}_{4}\right)_{2} / 100 \mathrm{mg}$ GF and $\mathrm{Mn}_{3}\left(\mathrm{PO}_{4}\right)_{2} / 150 \mathrm{mg}$ GF composites using $100 \mathrm{mg}$ and $150 \mathrm{mg}$ GF respectively.

\subsection{Structural, morphological and composition characterization}

X-ray diffraction (XRD) analysis of as-prepared $\mathrm{Mn}_{3}\left(\mathrm{PO}_{4}\right)_{2}$ sample and $\mathrm{Mn}_{3}\left(\mathrm{PO}_{4}\right)_{2} / \mathrm{GF}$ composites was carried out using XPERT-PRO diffractometer (PANalytical BV, Netherlands) with theta/2 theta geometry, operating with a cobalt tube at $50 \mathrm{kV}$ and $30 \mathrm{~mA}$. A T64000 micro-Raman spectrometer (HORIBA Scientific, Jobin Yvon Technology) with a $514 \mathrm{~nm}$ laser wavelength and spectral acquisition time of $120 \mathrm{~s}$ was used to characterize the as-prepared $\mathrm{Mn}_{3}\left(\mathrm{PO}_{4}\right)_{2}$ sample and $\mathrm{Mn}_{3}\left(\mathrm{PO}_{4}\right)_{2} / \mathrm{GF}$ composites. The Raman system laser power was set as low as $3 \mathrm{~mW}$ in order to minimize heating effects. The scanning electron microscopy (SEM) images were obtained using a Zeiss Ultra Plus 55 field emission scanning electron microscope (FE-SEM) operated at $1.0 \mathrm{kV}$ and equipped with an energy-dispersive $\mathrm{X}$-ray spectrometer (EDS). Both SEM and EDS were used to obtain the morphology and the composition of the as-prepared $\mathrm{Mn}_{3}\left(\mathrm{PO}_{4}\right)_{2}$ sample and $\mathrm{Mn}_{3}\left(\mathrm{PO}_{4}\right)_{2} / \mathrm{GF}$ composites. For highresolution transmission electron microscopy (HRTEM) analysis the ethanol solution containing the as-prepared materials was dispersed on a formal-coated copper grid and the analysis was carried out on a Jeol JEM-2100F Field Emission Electron Microscope with a maximum analytical resolution of $200 \mathrm{kV}$ and a probe size of $<0.5 \mathrm{~nm}$.

\subsection{Electrochemical characterization}

The fabrication of working electrodes was carried out as follows: Briefly, the as-prepared materials $\left(\mathrm{Mn}_{3}\left(\mathrm{PO}_{4}\right)_{2}\right.$ and $\mathrm{Mn}_{3}\left(\mathrm{PO}_{4}\right)_{2} / \mathrm{GF}$ composites), carbon black (to improve conductivity) and polyvinylidene fluoride (PVDF) binder were mixed in a mass ratio of 
80:10:10 and dispersed in N-methylpyrrolidone (NMP) solution. Then the resulting mixture was coated onto the nickel foam substrate $\left(1 \mathrm{~cm}^{2}\right)$, followed by drying at $60{ }^{\circ} \mathrm{C}$ for $12 \mathrm{~h}$ in a vacuum oven. The loading mass of each electrode was $3 \mathrm{mg}$.

The electrochemical behavior of $\mathrm{Mn}_{3}\left(\mathrm{PO}_{4}\right)_{2}$ and $\mathrm{Mn}_{3}\left(\mathrm{PO}_{4}\right)_{2} / \mathrm{GF}$ electrodes was studied using a three-electrode cell with glassy carbon as a counter electrode which passes the same current as the working electrode and $\mathrm{Ag} / \mathrm{AgCl}(3 \mathrm{M} \mathrm{KCl})$ as a reference electrode to measure the potential of the working electrode. The $6 \mathrm{M} \mathrm{KOH}$ aqueous electrolyte was used because of its high ionic conductivity of $\mathrm{K}^{+}$and $\mathrm{OH}^{-}\left(73.5\right.$ and $198 \mathrm{~S} \mathrm{~cm}^{2} \mathrm{~mol}^{-1}$ respectively) [29]. In the evaluation of the electrochemical performance of $\mathrm{Mn}_{3}\left(\mathrm{PO}_{4}\right)_{2}$ and $\mathrm{Mn}_{3}\left(\mathrm{PO}_{4}\right)_{2} / \mathrm{GF}$ electrodes, cyclic voltammetry (CV), galvanostatic charge/discharge (CD), and electrochemical impedance spectroscopy (EIS) were measured by a Bio-logic VMP-300 potentiostat. Cyclic voltammetry analysis was carried out at different scan rates from 5 to $100 \mathrm{mV} \mathrm{s}^{-1}$ within a positive potential window range of 0.0 to $0.4 \mathrm{~V}$ vs. $\mathrm{Ag} / \mathrm{AgCl}$. The galvanostatic chargedischarge analysis was carried out at different current densities in the range of 0.5 to $10.0 \mathrm{~A} \mathrm{~g}^{-1}$ in a potential window range of $0.0 \mathrm{~V}$ to $0.4 \mathrm{~V}$ vs. $\mathrm{Ag} / \mathrm{AgCl}$. The electrochemical impedance spectroscopy was carried out in an open-circuit potential and in a range of $10 \mathrm{mHz}$ to $100 \mathrm{mHz}$ frequencies. The electrochemical performance of $\mathrm{Mn}_{3}\left(\mathrm{PO}_{4}\right)_{2} / \mathrm{GF}$ electrode was also evaluated in a two-electrode cell (i.e. asymmetric cell device). In twoelectrode asymmetric cell device, $\mathrm{Mn}_{3}\left(\mathrm{PO}_{4}\right)_{2} / 100 \mathrm{mg}$ GF electrode served as a positive electrode and AC from coconut shell as a negative electrode. A detailed preparation of AC from coconut shell is given by Barzegar et al. [30]. Asymmetric cell device was carried out in a configuration of coin-type cells with a thickness of $0.2 \mathrm{~mm}$ and diameter of $16 \mathrm{~mm}$, using a glass microfiber filter paper as the separator in a $6 \mathrm{M} \mathrm{KOH}$ aqueous electrolyte.

\section{RESULTS AND DISCUSSION}

\subsection{Structural, morphological and composition characterization}

Figure 1(a) shows the XRD of the as-prepared manganese phosphate sample and the matching Inorganic Crystal Structure Database (ICSD) card no. 23541 (chemical formula: $\mathrm{Mn}_{3}\left(\mathrm{PO}_{4}\right)_{2}$; crystal system: monoclinic; space-group: $\mathrm{P} 121 / \mathrm{c} 1$; cell ratio $a / b=0.8904, b / c=$ 0.4159 and $c / a=2.7002$ ). XRD pattern of the as-prepared manganese phosphate shows welldefined crystalline peaks and the matching ICSD card number suggest that the as-prepared manganese phosphate has a chemical formula $\mathrm{Mn}_{3}\left(\mathrm{PO}_{4}\right)_{2}$. Figure 1(b) shows the crystal 
structure of $\mathrm{Mn}_{3}\left(\mathrm{PO}_{4}\right)_{2}$ viewed in the (-226) plane obtained using ICSD card no. 23541. In the $\mathrm{Mn}_{3}\left(\mathrm{PO}_{4}\right)_{2}$ structure, each phosphorus $(\mathrm{P})$ atom is surrounded tetrahedrally by four oxygen atoms with an average bond distance value of $1.54 \AA$ [31]. The phosphate has strong P-O covalent bonds which make $\mathrm{Mn}_{3}\left(\mathrm{PO}_{4}\right)_{2}$ structure chemically very stable. P-O bonds share an edge involving two strong oxygen atom bonds with the Mn. In addition, the structure shows five nearest Mn-O bonds with bonds distances ranging from 2.13 to $2.19 \AA$ and a sixth oxygen atom at a bond distance much greater than $2.19 \AA$ [31]. Consequently, divalent Mn can be regarded as unstable if coordinated to less than five oxygen atoms, hence the $\mathrm{Mn}_{3}\left(\mathrm{PO}_{4}\right)_{2}$ structure would distort in such a manner as to achieve the coordination number of at least five oxygen atoms. This could be the driving force which generates the formation of the $\mathrm{Mn}_{3}\left(\mathrm{PO}_{4}\right)_{2}$ structure. Figure 1(c) shows the XRD of the as-prepared $\mathrm{Mn}_{3}\left(\mathrm{PO}_{4}\right)_{2}$ and $\mathrm{Mn}_{3}\left(\mathrm{PO}_{4}\right)_{2} / \mathrm{GF}$ composites at different GF mass loading. It can be seen that with GF mass loading the XRD pattern of the $\mathrm{Mn}_{3}\left(\mathrm{PO}_{4}\right)_{2}$ remains unaltered. A (002) peak at $31.2^{\circ}$ which corresponds to graphene confirms the presence of GF in the $\mathrm{Mn}_{3}\left(\mathrm{PO}_{4}\right)_{2} / \mathrm{GF}$ composites.

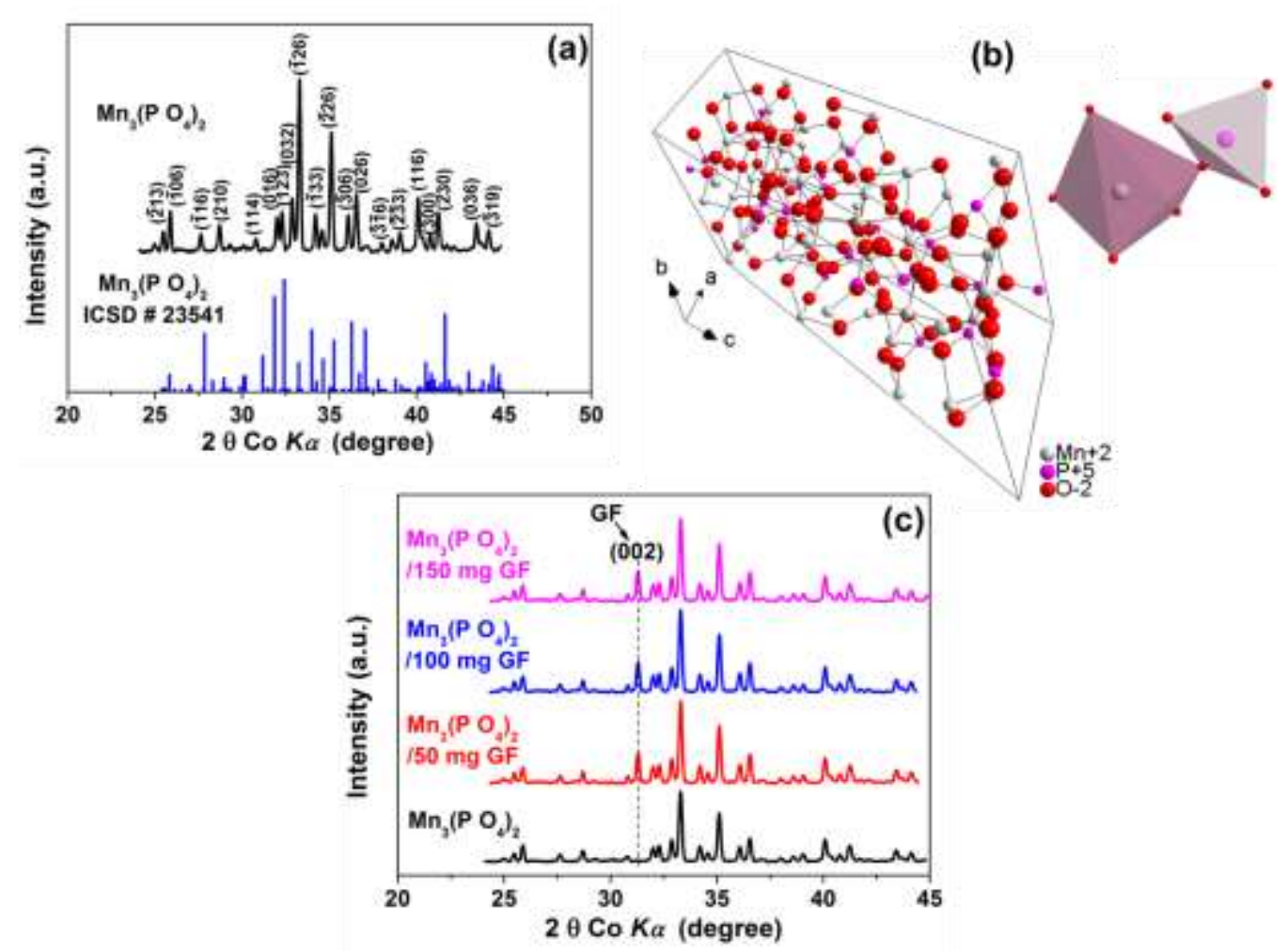

Figure 1. (a) The X-ray diffraction of the as-prepared $\mathrm{Mn}_{3}\left(\mathrm{PO}_{4}\right)_{2}$ sample and the matching $\mathrm{Mn}_{3}\left(\mathrm{PO}_{4}\right)_{2}$ ICSD card no. 23541. (b) The crystal structure of $\mathrm{Mn}_{3}\left(\mathrm{PO}_{4}\right)_{2}$ viewed in the (-226) plane obtained using ICSD card no. 23541. (c) The X-ray diffraction of the as-prepared $\mathrm{Mn}_{3}\left(\mathrm{PO}_{4}\right)_{2}$ and $\mathrm{Mn}_{3}\left(\mathrm{PO}_{4}\right)_{2} / \mathrm{GF}$ composites at different GF mass loading. 
Figure 2 shows the Raman spectroscopy analysis of the as-prepared $\mathrm{Mn}_{3}\left(\mathrm{PO}_{4}\right)_{2}$ and $\mathrm{Mn}_{3}\left(\mathrm{PO}_{4}\right)_{2} / \mathrm{GF}$ composites at different GF mass loading. In figure 2, the Raman spectrum of as-prepared GF is also shown. Since Raman spectroscopy is very sensitive to stretching vibrations in molecules it can be used to identify different phases at the molecular level. In figure 2, the strong sharp Raman band at $950 \mathrm{~cm}^{-1}$ is assigned to the $\mathrm{Mn}_{3}\left(\mathrm{PO}_{4}\right)_{2}$ stretching mode (see Raman spectrum for as-prepared $\mathrm{Mn}_{3}\left(\mathrm{PO}_{4}\right)_{2}$ ) [32]. In addition, the sharp Raman band at $950 \mathrm{~cm}^{-1}$ shows low-intensity features just above $950 \mathrm{~cm}^{-1}$ assigned to the $\mathrm{Mn}_{3}\left(\mathrm{PO}_{4}\right)_{2}$ signatures. The as-prepared graphene foam shows a typical Raman spectrum of graphene which depicts G-mode (carbon-carbon vibration mode) at $1570 \mathrm{~cm}^{-1}$ and 2D-mode (originating from the double resonance process) at $2710 \mathrm{~cm}^{-1}$. Similar to XRD data of the asprepared $\mathrm{Mn}_{3}\left(\mathrm{PO}_{4}\right)_{2}$ and $\mathrm{Mn}_{3}\left(\mathrm{PO}_{4}\right)_{2} / \mathrm{GF}$ composites at different GF mass loading, the $\mathrm{G}$ and 2D modes confirms the presence of GF in the composites. $\mathrm{Mn}_{3}\left(\mathrm{PO}_{4}\right)_{2} / 50 \mathrm{mg}$ GF composite shows strong sharp Raman band at $950 \mathrm{~cm}^{-1}$ similar to the $\mathrm{Mn}_{3}\left(\mathrm{PO}_{4}\right)_{2}$, however, at higher GF mass loading (i.e. $\mathrm{Mn}_{3}\left(\mathrm{PO}_{4}\right)_{2} / 100 \mathrm{mg} \mathrm{GF}$ and $\mathrm{Mn}_{3}\left(\mathrm{PO}_{4}\right)_{2} / 150 \mathrm{mg}$ GF composites) the intensity is reduced significantly and that could be as a result of GF adhering to the surface of the $\mathrm{Mn}_{3}\left(\mathrm{PO}_{4}\right)_{2}$ micro-rods.

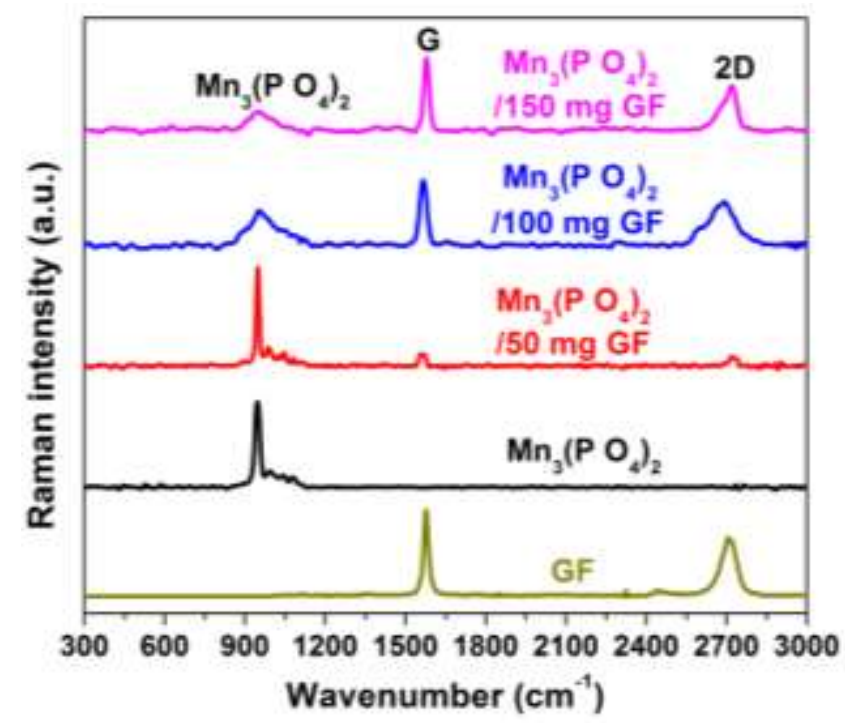

Figure 2. The Raman spectra of the as-prepared $\mathrm{Mn}_{3}\left(\mathrm{PO}_{4}\right)_{2}, \mathrm{Mn}_{3}\left(\mathrm{PO}_{4}\right)_{2} / \mathrm{GF}$ composites at different GF mass loading and that of graphene foam (GF).

Figure 3 shows the SEM micrographs which show the morphology of the as-prepared samples. Figure 3(a) and (b) (low and high magnification micrographs) show that the as- 
prepared $\mathrm{Mn}_{3}\left(\mathrm{PO}_{4}\right)_{2}$ sample is composed of hexagonal micro-rods. Figure 3(c) shows the micrograph of GF which depicts a typical sheet-like surface of CVD graphene. In composites, no deposition of the GF on the surface of the $\mathrm{Mn}_{3}\left(\mathrm{PO}_{4}\right)_{2}$ micro-rods is noticed in the $\mathrm{Mn}_{3}\left(\mathrm{PO}_{4}\right)_{2} / 50 \mathrm{mg}$ GF composite (Figure 3(d)), however, in the $\mathrm{Mn}_{3}\left(\mathrm{PO}_{4}\right)_{2} / 100 \mathrm{mg} \mathrm{GF}$ composite (Figure 3(e)) the deposition of the GF on the surface of the $\mathrm{Mn}_{3}\left(\mathrm{PO}_{4}\right)_{2}$ micro-rods is evident and in the $\mathrm{Mn}_{3}\left(\mathrm{PO}_{4}\right)_{2} / 150 \mathrm{mg}$ GF composite (Figure 3(f)) the micro-rods appear to be densely coated by GF. Though, the adhesion of GF on the surface of the $\mathrm{Mn}_{3}\left(\mathrm{PO}_{4}\right)_{2}$ microrods could increase the electrical conductivity of the material for improved electrochemical performance the dense coating would negatively affect the electrochemical performance by preventing any possible interaction between the $\mathrm{Mn}_{3}\left(\mathrm{PO}_{4}\right)_{2}$ and the electrolyte.
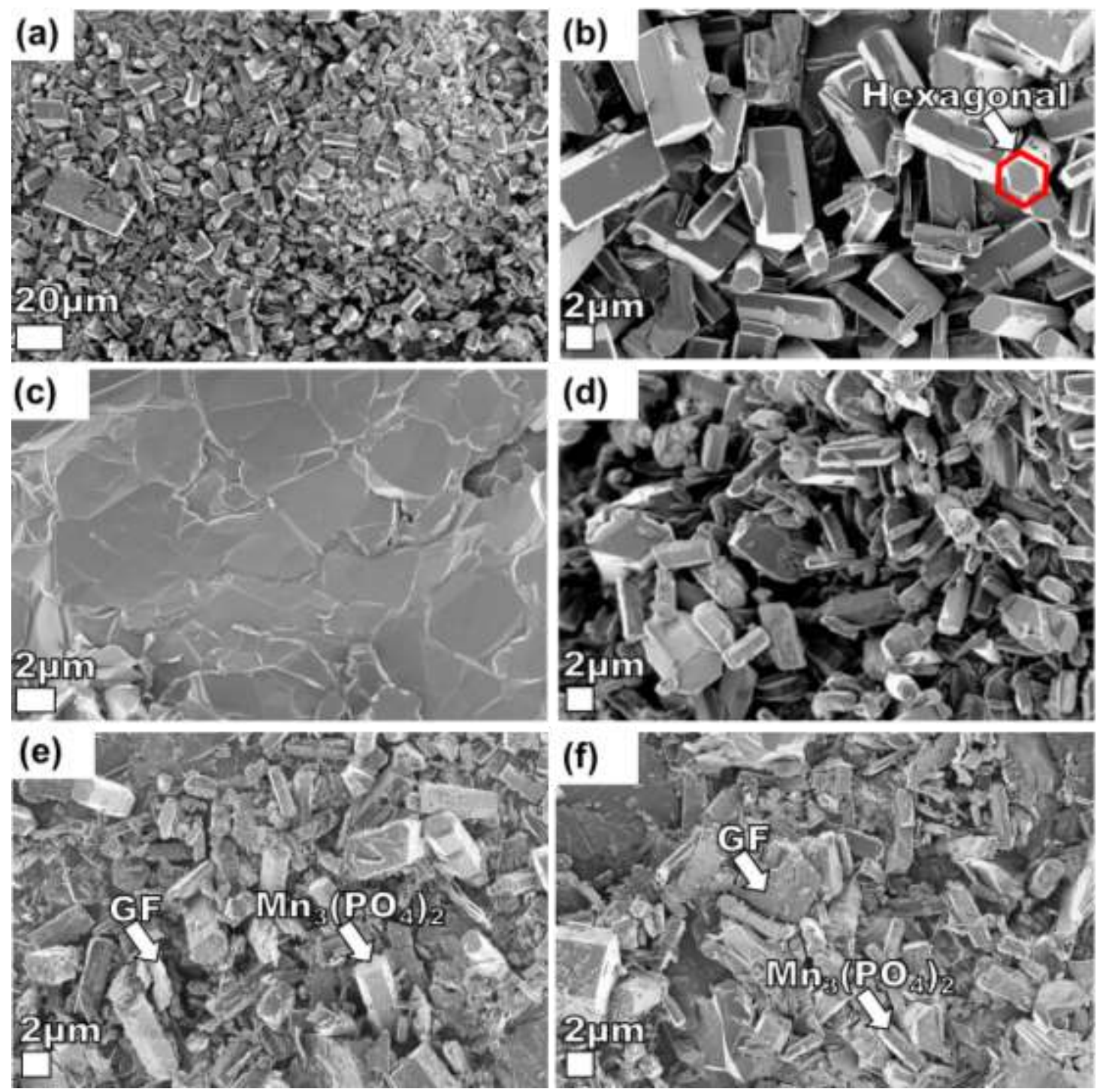

Figure 3. SEM micrographs of the as-prepared (a-b) $\mathrm{Mn}_{3}\left(\mathrm{PO}_{4}\right)_{2}$ sample at low and high magnification, (c) GF, (d) $\mathrm{Mn}_{3}\left(\mathrm{PO}_{4}\right)_{2} / 50 \mathrm{mg}$ GF composite, (e) $\mathrm{Mn}_{3}\left(\mathrm{PO}_{4}\right)_{2} / 100 \mathrm{mg}$ GF composite, (f) $\mathrm{Mn}_{3}\left(\mathrm{PO}_{4}\right)_{2} / 150 \mathrm{mg} \mathrm{GF}$ composite. 
The morphology of the as-prepared materials was further observed using HRTEM and the results are shown in figure 4. In accordance with the results obtained in the SEM (Figure 3), the HRTEM image of the as-prepared $\mathrm{Mn}_{3}\left(\mathrm{PO}_{4}\right)_{2}$ (Figure 4(a)) show micro-rods with the average thickness estimated around $1 \mu \mathrm{m}$, and this material exhibited the selected area electron diffraction (SAED) pattern in figure 4 (b). This SAED pattern shows clear diffraction spots (rings) and this confirms the polycrystalline nature of the material which is in agreement with the XRD data. In composites, it is evident that $\mathrm{Mn}_{3}\left(\mathrm{PO}_{4}\right)_{2}$ micro-rods are coated by GF as shown in figure 4(c) for $\mathrm{Mn}_{3}\left(\mathrm{PO}_{4}\right)_{2} / 100 \mathrm{mg}$ GF composite, and this also confirms a typical sheet-like surface of GF.
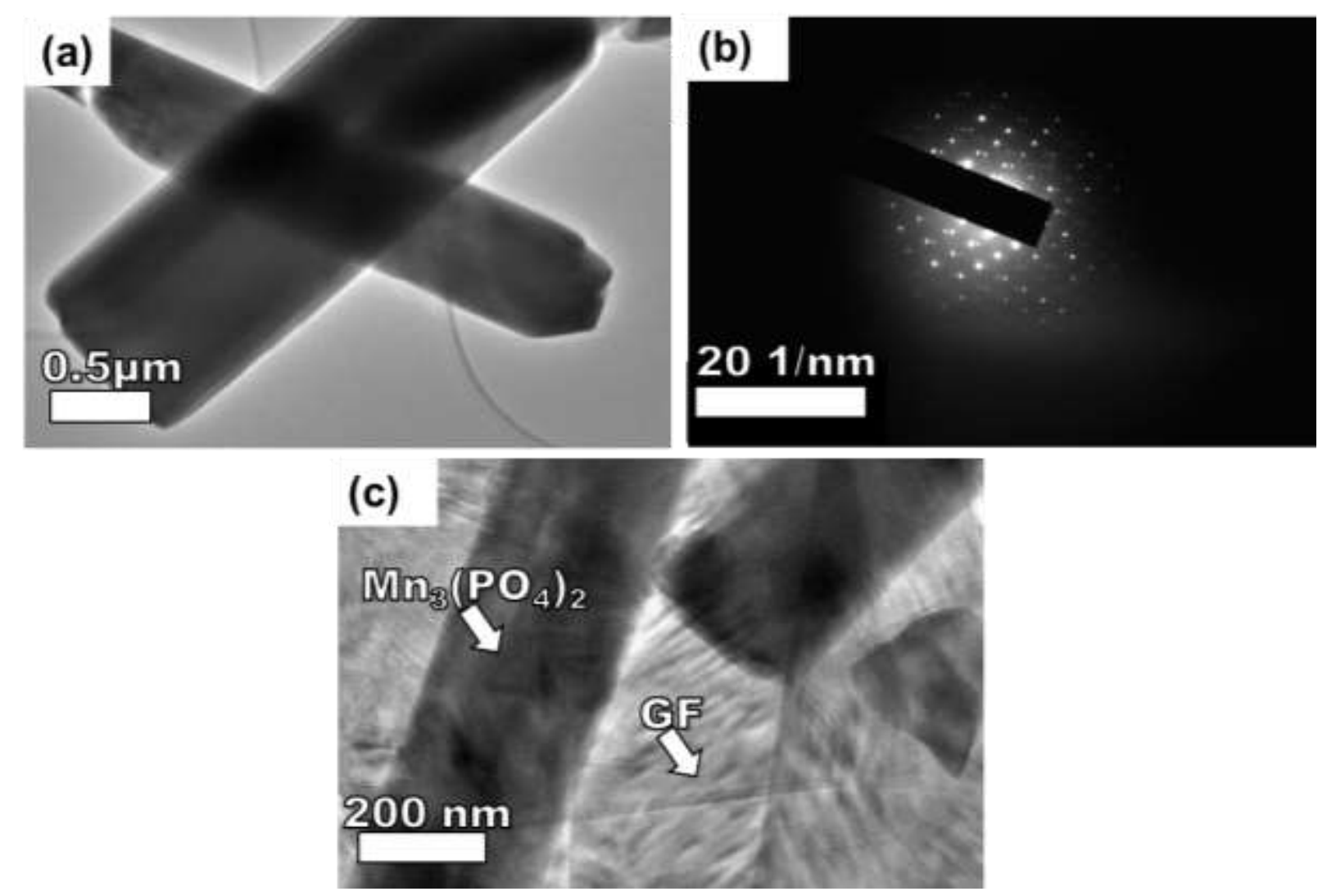

Figure 4. An HRTEM image of as-prepared (a) $\mathrm{Mn}_{3}\left(\mathrm{PO}_{4}\right)_{2}$ sample and (b) the corresponding selected area electron diffraction pattern, and an HRTEM image of $\mathrm{Mn}_{3}\left(\mathrm{PO}_{4}\right)_{2} / 100 \mathrm{mg}$ GF composite.

EDS analysis was carried out to show the elemental composition of the as-prepared $\mathrm{Mn}_{3}\left(\mathrm{PO}_{4}\right)_{2}$ and $\mathrm{Mn}_{3}\left(\mathrm{PO}_{4}\right)_{2} / \mathrm{GF}$ composites at different GF mass loading. The EDS analysis (Figure 5) confirmed the presence of $\mathrm{Mn}, \mathrm{P}$, and $\mathrm{O}$ in the $\mathrm{Mn}_{3}\left(\mathrm{PO}_{4}\right)_{2}$ and also $\mathrm{C}$ in $\mathrm{Mn}_{3}\left(\mathrm{PO}_{4}\right)_{2} / \mathrm{GF}$ composites. It is worth mentioning that the Mn peak at about $0.25 \mathrm{keV}$ 
overlaps with that of C. Despite the overlapping, an observed systematic increase in the peak intensity with GF mass loading shows an increase in $\mathrm{C}$ content of the composites.
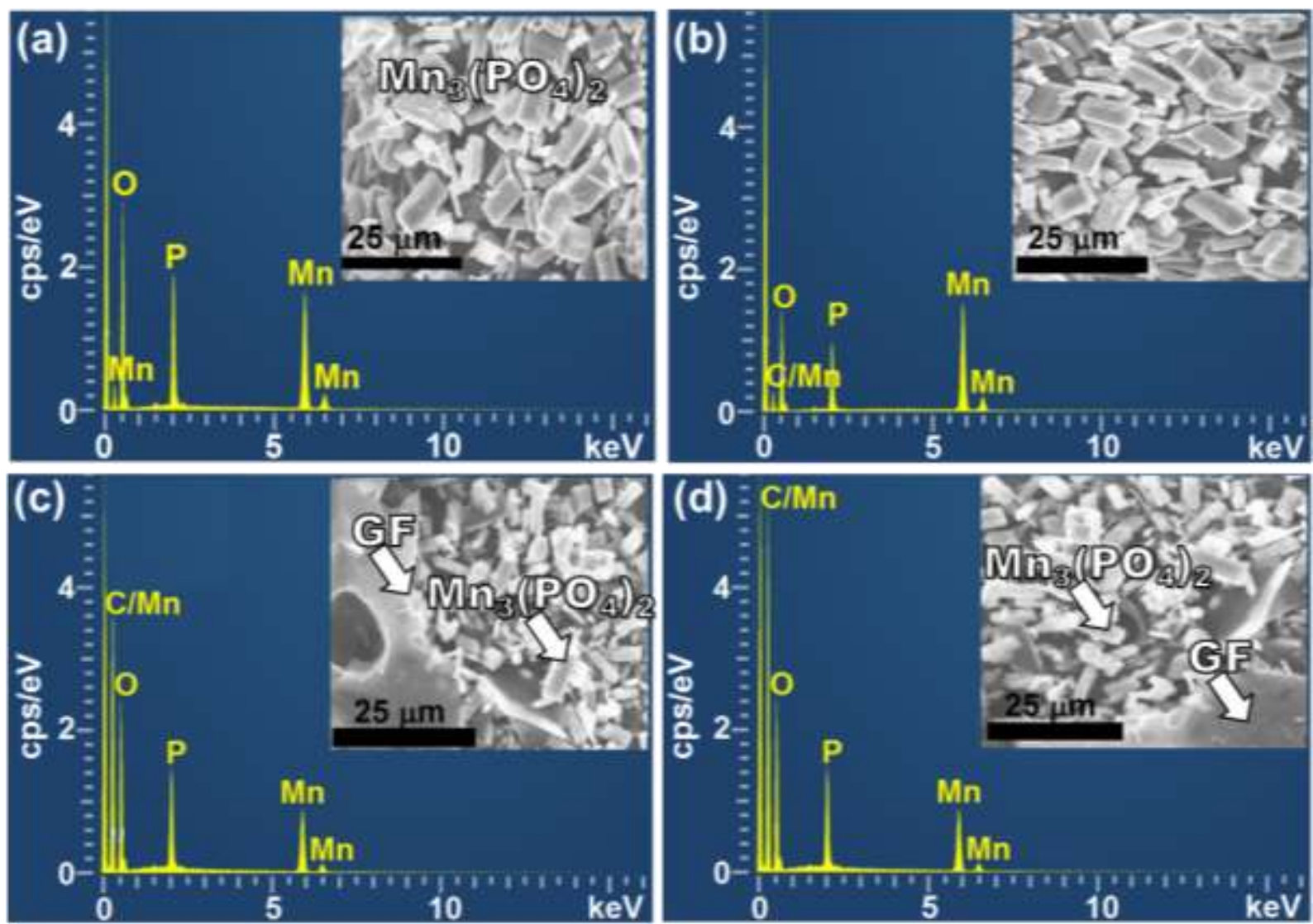

Figure 5. (a) EDS spectra of the as-prepared (a) $\mathrm{Mn}_{3}\left(\mathrm{PO}_{4}\right)_{2}$ sample and $\mathrm{Mn}_{3}\left(\mathrm{PO}_{4}\right)_{2} / \mathrm{GF}$ composites at (b) $50 \mathrm{mg}$ GF, (c) $100 \mathrm{mg}$ GF and (d) $150 \mathrm{mg}$ GF. The insert figures (secondary electron beam images) show areas where each EDS spectra were obtained.

\subsection{Electrochemical characterization}

Figure 6(a) shows curves of $\mathrm{Ni}$ foam and Ni-GF at a scan rate of $50 \mathrm{mVs}^{-1}$ in a potential window range of $0.0-0.4 \mathrm{~V}$. A pair of redox peaks corresponding to anodic peak around $\sim 0.2 \mathrm{~V}$ and cathodic peak around $\sim 0.35$ is observed, confirming the faradic properties of the $\mathrm{Ni}$ foam and Ni-GF. Figure 6(b) shows $\mathrm{CV}$ curves of the as-prepared $\mathrm{Mn}_{3}\left(\mathrm{PO}_{4}\right)_{2}$ and $\mathrm{Mn}_{3}\left(\mathrm{PO}_{4}\right)_{2} / \mathrm{GF}$ composites at different GF mass loading measured at a scan rate of $50 \mathrm{mVs}^{-1}$ in a potential window range of 0.0 to $0.4 \mathrm{~V}$ vs. $\mathrm{Ag} / \mathrm{AgCl}$. These $\mathrm{CV}$ curves show a reduction and oxidation peaks at $\sim 0.2 \mathrm{~V}$ and $\sim 0.3 \mathrm{~V}$ respectively, due to electrochemical redox reactions at an interface between electrode and electrolyte corresponding to the reversible reaction of $\mathrm{Mn}^{2+}$ and $\mathrm{Mn}^{3+}$ which indicate the pseudocapacitive behavior of the electrodes 
[5]. It can be seen that an addition of $50 \mathrm{mg} \mathrm{GF}$ into $\mathrm{Mn}_{3}\left(\mathrm{PO}_{4}\right)_{2}$ improves the current response of the electrode, as shown for $\mathrm{Mn}_{3}\left(\mathrm{PO}_{4}\right)_{2} / 50 \mathrm{mg}$ GF composite electrode. However, for $\mathrm{Mn}_{3}\left(\mathrm{PO}_{4}\right)_{2} / 100 \mathrm{mg}$ GF composite electrode the current response appear similar to that of $\mathrm{Mn}_{3}\left(\mathrm{PO}_{4}\right)_{2} / 50 \mathrm{mg} \mathrm{GF}$ composite electrode suggesting that this electrode has reached maximum current response. Though, $\mathrm{Mn}_{3}\left(\mathrm{PO}_{4}\right)_{2} / 50 \mathrm{mg} \mathrm{GF}$ and $\mathrm{Mn}_{3}\left(\mathrm{PO}_{4}\right)_{2} / 100 \mathrm{mg} \mathrm{GF}$ electrodes show similar current response the two electrodes display redox peaks at different potential positions. For instance, $\mathrm{Mn}_{3}\left(\mathrm{PO}_{4}\right)_{2} / 100 \mathrm{mg}$ GF electrode shows reduction and oxidation peaks at lower potential positions, i.e. $\sim 0.14 \mathrm{~V}$ and $\sim 0.24 \mathrm{~V}$ respectively while $\mathrm{Mn}_{3}\left(\mathrm{PO}_{4}\right)_{2} / 50 \mathrm{mg}$ GF electrode shows reduction and oxidation peaks at $\sim 0.2 \mathrm{~V}$ and $\sim 0.3 \mathrm{~V}$ respectively, almost similar to as-prepared $\mathrm{Mn}_{3}\left(\mathrm{PO}_{4}\right)_{2}$ electrode. This behavior of $\mathrm{Mn}_{3}\left(\mathrm{PO}_{4}\right)_{2} / 100 \mathrm{mg}$ GF electrode could be attributed to nearly equal contributions of the Faradic and EDLC from $\mathrm{Mn}_{3}\left(\mathrm{PO}_{4}\right)_{2}$ and carbon (or GF) respectively resulting in high electrochemical performance. A CV curve of $\mathrm{Mn}_{3}\left(\mathrm{PO}_{4}\right)_{2} / 150 \mathrm{mg}$ GF composite shows nearly rectangular shape suggesting a dominating EDLC behavior of the electrode which could be due to a high carbon content that is densely attached to $\mathrm{Mn}_{3}\left(\mathrm{PO}_{4}\right)_{2}$ preventing any possible interaction between the $\mathrm{Mn}_{3}\left(\mathrm{PO}_{4}\right)_{2}$ and the electrolyte. The observed low current response of the as-prepared $\mathrm{Mn}_{3}\left(\mathrm{PO}_{4}\right)_{2}$ electrode is due to the sluggish nature of the material, which drastically decreases the electrical conductivity of the material. Figure 6(c) shows CV curves of the $\mathrm{Mn}_{3}\left(\mathrm{PO}_{4}\right)_{2} / 100 \mathrm{mg}$ GF composite at a scan rate of 5, 10, 20, 50 and $100 \mathrm{mV} \mathrm{s}^{-1}$ in a potential window range of 0.0 to $0.4 \mathrm{~V}$ vs. $\mathrm{Ag} / \mathrm{AgCl}$. In this figure, as the scan rate increases the current response increases gradually suggesting good reversibility during the fast chargedischarge process of the electrolyte, active material and the interface. At a high scan rate of $100 \mathrm{mV} \mathrm{s}^{-1}$ the potential difference between the anodic and cathodic peaks increases due to the polarization of electrode. 

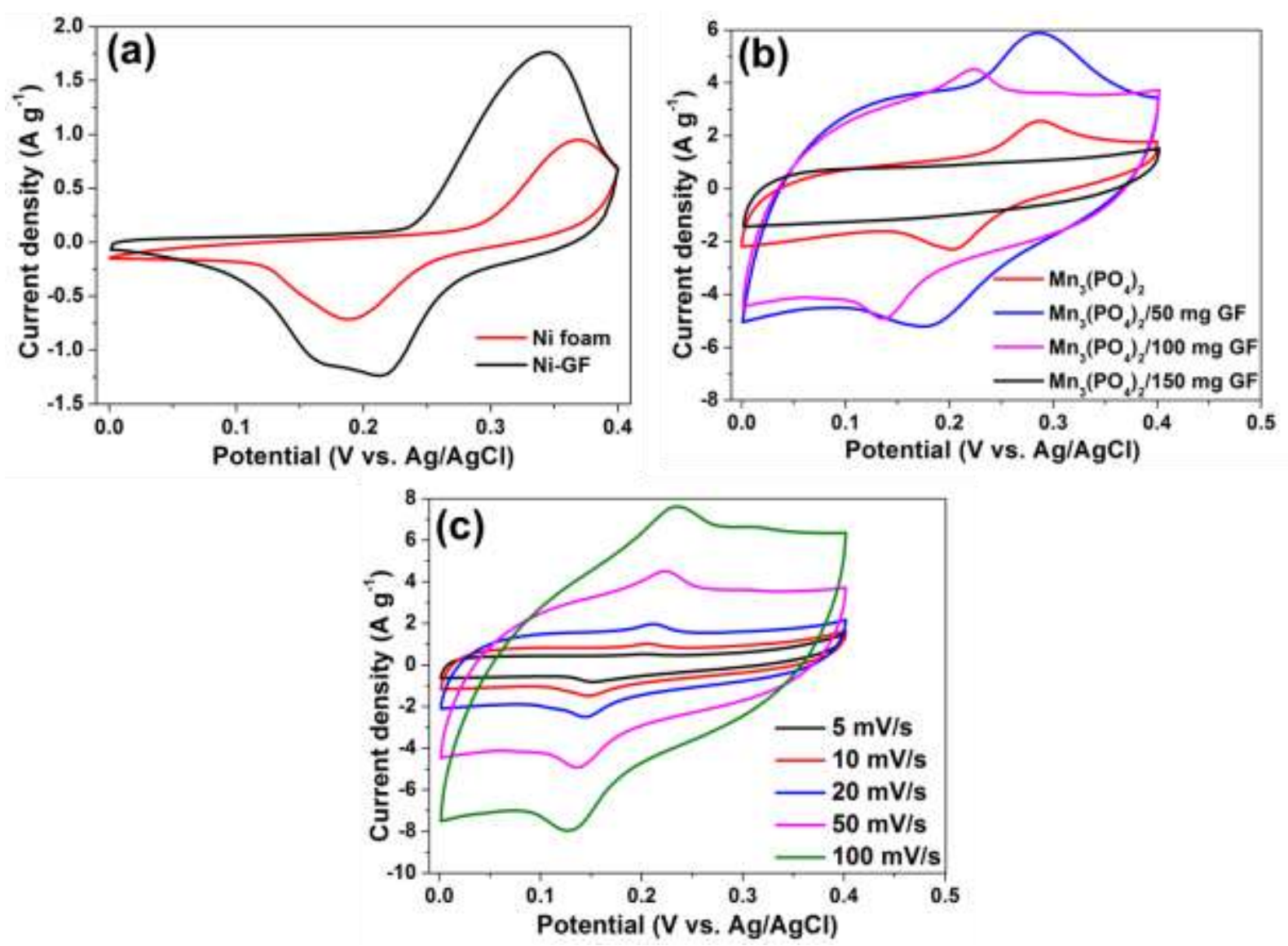

Figure 6. (a) $\mathrm{CV}$ curves of the $\mathrm{Ni}$ foam and $\mathrm{Ni}-\mathrm{GF}$ at a scan rate of $50 \mathrm{mV} \mathrm{s}^{-1}$. (b) $\mathrm{CV}$ curves of the as-prepared $\mathrm{Mn}_{3}\left(\mathrm{PO}_{4}\right)_{2}$ and $\mathrm{Mn}_{3}\left(\mathrm{PO}_{4}\right)_{2} / \mathrm{GF}$ composites at different GF mass loading measured at a scan rate of $50 \mathrm{mV} \mathrm{s}^{-1}$ in a potential window range of 0.0 to $0.4 \mathrm{~V}$ vs. $\mathrm{Ag} / \mathrm{AgCl}$. (c) $\mathrm{CV}$ curves of the $\mathrm{Mn}_{3}\left(\mathrm{PO}_{4}\right)_{2} / 100 \mathrm{mg}$ GF composite electrode at a scan rate of $5,10,20,50$ and $100 \mathrm{mV} \mathrm{s}^{-1}$ in a potential window range of 0.0 to $0.4 \mathrm{~V} \mathrm{vs.} \mathrm{Ag} / \mathrm{AgCl}$.

Figure 7(a) shows the $\mathrm{CD}$ curves of the as-prepared $\mathrm{Mn}_{3}\left(\mathrm{PO}_{4}\right)_{2}$ and $\mathrm{Mn}_{3}\left(\mathrm{PO}_{4}\right)_{2} / \mathrm{GF}$ composites at different GF mass loading measured at a current density of $0.5 \mathrm{~A} \mathrm{~g}^{-1}$ in a potential window range of 0.0 to $0.4 \mathrm{~V}$ vs. $\mathrm{Ag} / \mathrm{AgCl}$. The $\mathrm{CD}$ curves of the $\mathrm{Mn}_{3}\left(\mathrm{PO}_{4}\right)_{2}$, $\mathrm{Mn}_{3}\left(\mathrm{PO}_{4}\right)_{2} / 50 \mathrm{mg}$ GF and $\mathrm{Mn}_{3}\left(\mathrm{PO}_{4}\right)_{2} / 100 \mathrm{mg}$ GF electrodes show potential steps, i.e. a fast potential drop $(0.4-0.28 \mathrm{~V})$ and a slow potential drop $(0.28-0.18 \mathrm{~V})$ which indicates the Faradaic behavior part of the electrodes. In contrast, $\mathrm{Mn}_{3}\left(\mathrm{PO}_{4}\right)_{2} / 150 \mathrm{mg}$ GF electrode shows a linear CD curve attributed to the dominating EDLC part of the electrode. In addition to the observed high current response of $\mathrm{Mn}_{3}\left(\mathrm{PO}_{4}\right)_{2} / 100 \mathrm{mg}$ GF electrode in figure 6(c), this electrode further shows the longest discharge time (Figure 7(a)) suggesting a better rate of discharge and high specific capacitance compare to other electrodes. This could be attributed to the appropriate quantity of graphene foam in $\mathrm{Mn}_{3}\left(\mathrm{PO}_{4}\right)_{2}$ which would mediate an effective interaction between the $\mathrm{Mn}_{3}\left(\mathrm{PO}_{4}\right)_{2}$ and the electrolyte. Furthermore, since the working 
electrodes show Faradic behavior the specific capacitance, $C_{\mathrm{S}}\left(\mathrm{F}^{-1}\right)$ was calculated by integrating the area under the CD curve using the following equation [33-35]:

$C_{\mathrm{S}}=\frac{2 I}{m V^{2}} \int V d t$

while for EDLC supercapacitors, the specific capacitance can be calculated using the following equation:

$$
C_{\mathrm{S}}=\frac{I \times \Delta t}{m \times \Delta V}
$$

The specific capacitance calculated using equation 1 was further converted to the equivalent specific capacity, $Q\left(\mathrm{~mA} \mathrm{~h} \mathrm{~g}^{-1}\right)$ over a potential, $V(\mathrm{~V})$ according to the following equations [36]:

$C_{\mathrm{S}}=\frac{3.6 Q}{V}$

$Q=\frac{V C_{\mathrm{S}}}{3.6}$

where $\boldsymbol{I}$ is the current density in $\mathrm{mA}, m$ is the total mass of the active material in $\mathrm{mg}, V$ is the potential window in volts $(\mathrm{V})$, and $t$ is the time in seconds taken for a complete discharge cycle.

Figure 7(b) shows the calculated specific capacitance and the corresponding specific capacity of the as-prepared $\mathrm{Mn}_{3}\left(\mathrm{PO}_{4}\right)_{2}$ and $\mathrm{Mn}_{3}\left(\mathrm{PO}_{4}\right)_{2} / \mathrm{GF}$ composites at different GF mass loading plotted as a function of current densities in the range of 0.5 to $10.0 \mathrm{~A} \mathrm{~g}^{-1}$. In figure 7(b), it is clear that the specific capacitance continuously decreases with increasing current density and that could be as a result of increased redox reactions due to high applied current density. Figure 7(c) shows the specific capacitance of $\mathrm{Mn}_{3}\left(\mathrm{PO}_{4}\right)_{2}$ and $\mathrm{Mn}_{3}\left(\mathrm{PO}_{4}\right)_{2} / \mathrm{GF}$ composites as a function of GF mass loading. This figure shows that when increasing the mass loading of GF up to $100 \mathrm{mg}$ the specific capacitance increases which is equivalent to the discharge time of a $\mathrm{CD}$ curve, and then decreases with increasing mass loading of GF up to $150 \mathrm{mg}$. The specific capacitance of the as-prepared $\mathrm{Mn}_{3}\left(\mathrm{PO}_{4}\right)_{2}, \mathrm{Mn}_{3}\left(\mathrm{PO}_{4}\right)_{2} / 50 \mathrm{mg} \mathrm{GF}, \mathrm{Mn}_{3}\left(\mathrm{PO}_{4}\right)_{2} / 100 \mathrm{mg}$ GF and $\mathrm{Mn}_{3}\left(\mathrm{PO}_{4}\right)_{2} / 150 \mathrm{mg}$ GF electrodes are 41, 90, 270 and $34 \mathrm{Fg}^{-1}$ respectively, at a current density of $0.5 \mathrm{~A} \mathrm{~g}^{-1}$. 
The excellent capacitive performance of $\mathrm{Mn}_{3}\left(\mathrm{PO}_{4}\right)_{2} / 100 \mathrm{mg}$ GF electrode can be attributed to the synergetic effect of the graphene foam and the Faradic contribution of $\mathrm{Mn}_{3}\left(\mathrm{PO}_{4}\right)_{2}$ which improves the electrical conductivity and reduce the ionic diffusion length during the chargedischarge process.
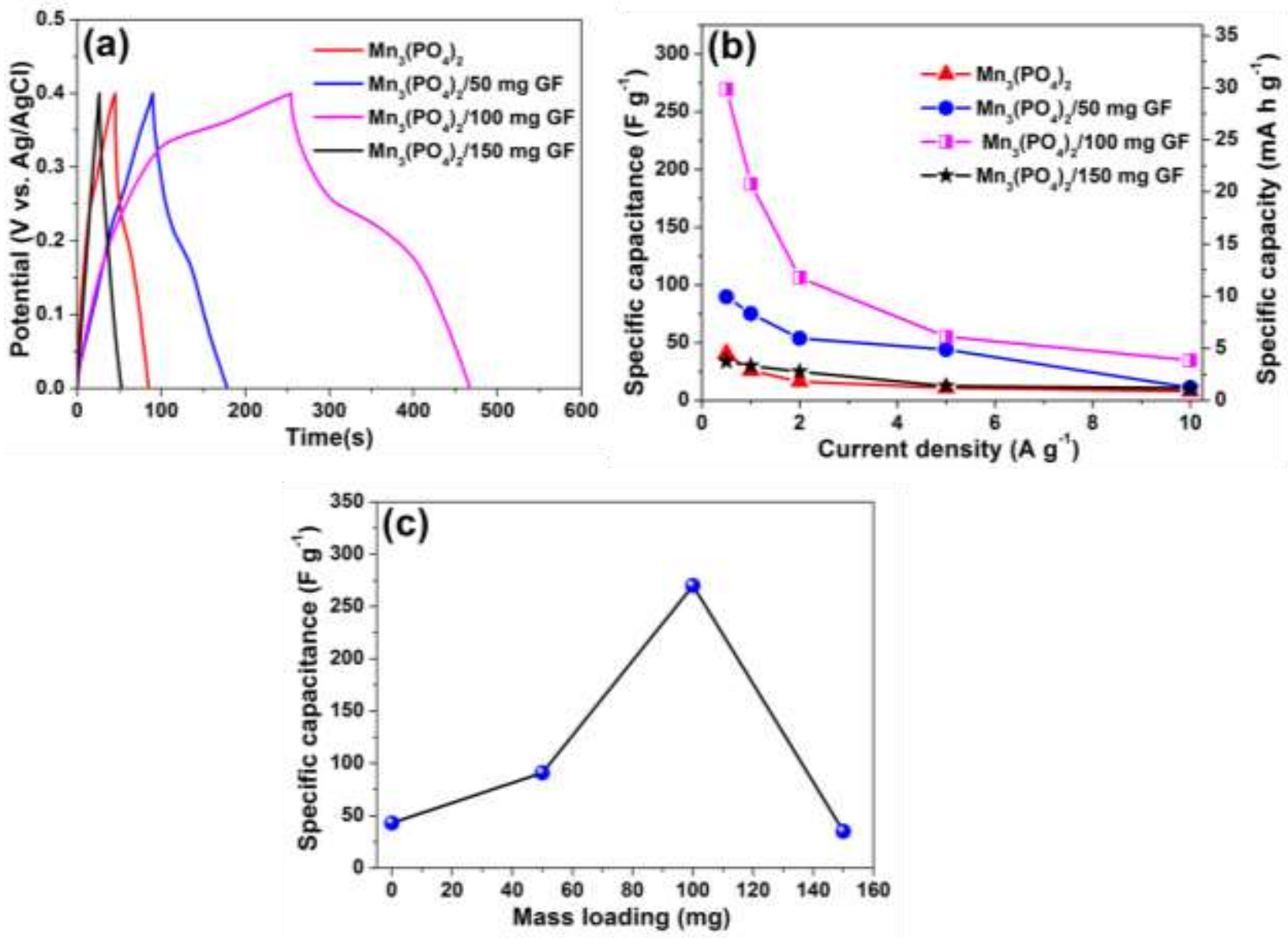

Figure 7. (a) $\mathrm{CD}$ curves of the as-prepared $\mathrm{Mn}_{3}\left(\mathrm{PO}_{4}\right)_{2}$ and $\mathrm{Mn}_{3}\left(\mathrm{PO}_{4}\right)_{2} / \mathrm{GF}$ composites at different GF mass loading measured at a current density of $0.5 \mathrm{~A} \mathrm{~g}^{-1}$ in a potential window range of 0.0 to $0.4 \mathrm{~V} \mathrm{vs}$. $\mathrm{Ag} / \mathrm{AgCl}$. (b) Specific capacitance and the corresponding specific capacity of the as-prepared $\mathrm{Mn}_{3}\left(\mathrm{PO}_{4}\right)_{2}$ and $\mathrm{Mn}_{3}\left(\mathrm{PO}_{4}\right)_{2} / \mathrm{GF}$ composites at different GF mass loading as a function of current density. (c) The specific capacitance of asprepared $\mathrm{Mn}_{3}\left(\mathrm{PO}_{4}\right)_{2}$ and $\mathrm{Mn}_{3}\left(\mathrm{PO}_{4}\right)_{2} / \mathrm{GF}$ composites as a function of GF mass loading.

Furthermore, to evaluate the key factors influencing the capacitive performance of electrode which are the electronic resistance of the electrode, the ionic resistance of the electrolyte, the charge-transfer resistance of the redox reactions, and the diffusive resistance of the electrolyte in the electrode, the EIS was carried out at the potential of $0.0 \mathrm{~V}$ and the 
frequency range of $10 \mathrm{mHz}$ to $100 \mathrm{mHz}$, including the galvanostatic cycling curves to evaluate the electrochemical stability of the electrode. Figure 8(a) shows the Nyquist plot (imaginary component, $Z^{\prime \prime}$ versus the real component, $\mathrm{Z}^{\prime}$ of the impedance) of the $\mathrm{Mn}_{3}\left(\mathrm{PO}_{4}\right)_{2}$, $\mathrm{Mn}_{3}\left(\mathrm{PO}_{4}\right) 2 / 50 \mathrm{mg} \mathrm{GF}, \mathrm{Mn}_{3}\left(\mathrm{PO}_{4}\right)_{2} / 100 \mathrm{mg} \mathrm{GF}$ and $\mathrm{Mn}_{3}\left(\mathrm{PO}_{4}\right)_{2} / 150 \mathrm{mg}$ GF electrodes. As it can be seen from the Nyquist plot, $\mathrm{Mn}_{3}\left(\mathrm{PO}_{4}\right)_{2}$ electrode shows electrolyte/solution resistance, $R_{\mathrm{S}}$ value of $0.52 \Omega$ (intercept to the $x$-axis, see inset to the figure) and following an addition of $50 \mathrm{mg}$ GF into $\mathrm{Mn}_{3}\left(\mathrm{PO}_{4}\right)_{2}$ the $R_{\mathrm{S}}$ value reduces to $0.40 \Omega$, and for $\mathrm{Mn}_{3}\left(\mathrm{PO}_{4}\right)_{2} / 100 \mathrm{mg} \mathrm{GF}$ electrode the $R_{\mathrm{S}}$ value further reduces to $0.25 \Omega$, however, for $\mathrm{Mn}_{3}\left(\mathrm{PO}_{4}\right)_{2} / 150 \mathrm{mg} \mathrm{GF}$ electrode the $R_{\mathrm{S}}$ value increases to $0.50 \Omega$. Consequently, $\mathrm{Mn}_{3}\left(\mathrm{PO}_{4}\right)_{2} / 100 \mathrm{mg}$ GF electrode shows a lower solution resistance which could be one of the reasons why this electrode has high capacitive performance. In figure 8(a), the electrodes exhibit a lower electrodeelectrolyte interface charge transfer resistance, $R_{\mathrm{CT}}$ (no noticeable semi-circle in the highfrequency region of the plot) which is affected by the kinetics of the electrode reactions and hence a better capacitive behavior.

Moreover, the $\mathrm{Mn}_{3}\left(\mathrm{PO}_{4}\right)_{2} / 100 \mathrm{mg}$ GF electrode also shows good cycling stability at a high current density of $5 \mathrm{~A} \mathrm{~g}^{-1}$, without any loss in the capacitance with $99 \%$ Columbic efficiency up to 1000 charge-discharge cycles, as shown in figure 8 (b). Now, after charge-discharge cycles, $R_{\mathrm{S}}$ value of $0.25 \Omega$ was obtained for $\mathrm{Mn}_{3}\left(\mathrm{PO}_{4}\right)_{2} / 100 \mathrm{mg}$ GF electrode (see the Nyquist plot in figure 8(c)) which is similar to that before cycling stability hence confirming good chemical/structural stability of the electrode. The excellent cycling stability of the $\mathrm{Mn}_{3}\left(\mathrm{PO}_{4}\right)_{2} / 100 \mathrm{mg}$ GF electrode could be attributed to $\mathrm{Mn}_{3}\left(\mathrm{PO}_{4}\right)_{2}$ structure which is chemically very stable. On the other hand, GF in $\mathrm{Mn}_{3}\left(\mathrm{PO}_{4}\right)_{2} / 100 \mathrm{mg}$ GF electrode could be viewed as enhancing the electrical conductivity of the electrode. Therefore, due to the combined effects of enhanced structural property and electrical conductivity of the composite electrode the electrode demonstrate good and promising electrochemical performance. 

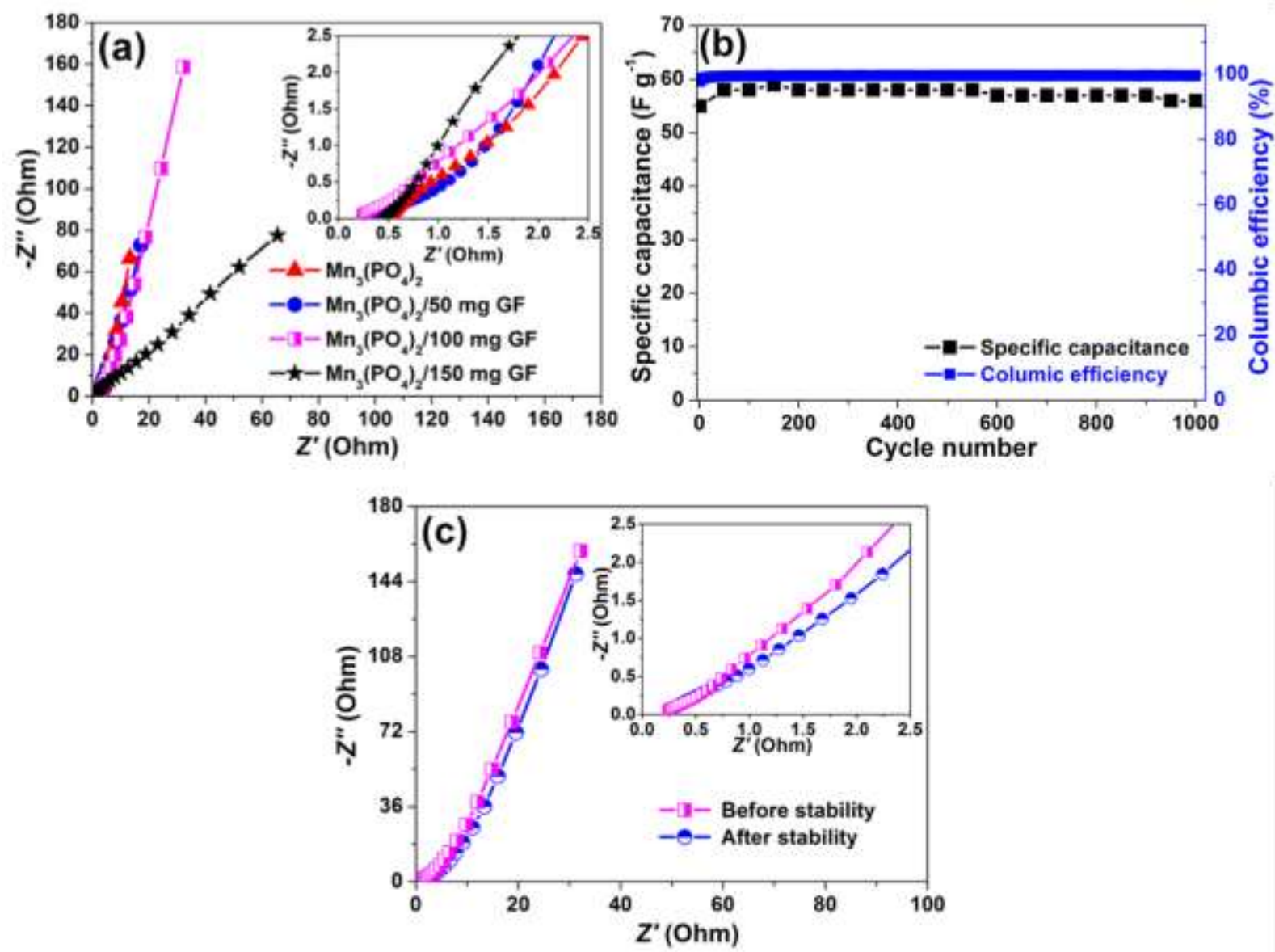

Figure 8. (a) Nyquist plot (imaginary component, $Z^{\prime \prime}$ versus the real component, $Z^{\prime}$ of the impedance) of the $\mathrm{Mn}_{3}\left(\mathrm{PO}_{4}\right)_{2}, \mathrm{Mn}_{3}\left(\mathrm{PO}_{4}\right)_{2} / \mathrm{GF}$ composites with different mass loading as shown in the figure (the inset shows the enlarged high-frequency region of the plot). (b) The cycling stability of the $\mathrm{Mn}_{3}\left(\mathrm{PO}_{4}\right)_{2} / 100 \mathrm{mg}$ GF electrode at a current density of $5 \mathrm{~A} \mathrm{~g} \mathrm{~g}^{-1}$. (c) Nyquist plot for the $\mathrm{Mn}_{3}\left(\mathrm{PO}_{4}\right)_{2} / 100 \mathrm{mg}$ GF electrode before and after cycling at a current density of $5 \mathrm{~A} \mathrm{~g}^{-1}$.

This work shows significant improvement on the specific capacitance of $\mathrm{Mn}_{3}\left(\mathrm{PO}_{4}\right)_{2} / 100 \mathrm{mg} \mathrm{GF}$ electrode compared with the specific capacitance values for manganese/metal phosphate-based electrodes evaluated in a three-electrode cell configuration published previously by other studies, as shown in figure 9 and the corresponding table 1 which summarise the electrochemical performances of these published results. 


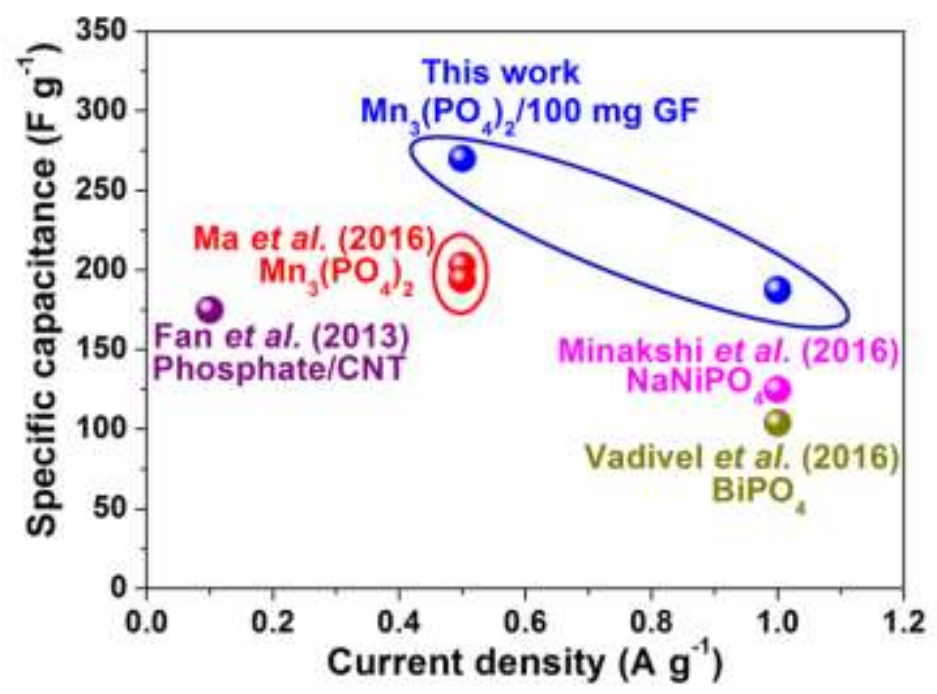

Figure 9. A comparison of specific capacitance of manganese/metal phosphate-based materials evaluated in three electrode for supercapacitor applications obtained in this work and previously published reports by Ma $e t$ al. [28], Fan et al. [37], Minakshi et al [38] and Vadivel et al [39].

Table 1. Electrochemical performances of recently published results on manganese/metal phosphate-based electrodes evaluated in a three-electrode cell configuration.

\begin{tabular}{|c|c|c|c|c|c|}
\hline Electrodes & $\begin{array}{l}\text { Synthesis } \\
\text { method }\end{array}$ & $\begin{array}{c}\text { Specific } \\
\text { capacitance } \\
(\mathbf{F} / \mathbf{g})\end{array}$ & Electrolyte & Cyclic performance & Ref. \\
\hline Phosphate/CNT & Hydrothermal & $170 @ 0.1 \mathrm{~A} / \mathrm{g}$ & $6 \mathrm{M} \mathrm{KOH}$ & $\begin{array}{l}100 \% \text { after } 2000 \\
\text { cycles @ } 5.0 \mathrm{~A} / \mathrm{g}\end{array}$ & [37] \\
\hline $\mathrm{NaNiPO}_{4}$ & Hydrothermal & $125 @ 0.1 \mathrm{~A} / \mathrm{g}$ & $2 \mathrm{M} \mathrm{NaOH}$ & $\begin{array}{l}99 \% \text { after } 2000 \\
\text { cycles@1.0 A/g }\end{array}$ & [38] \\
\hline $\mathrm{Mn}_{3}\left(\mathrm{PO}_{4}\right)_{2}$ & Hydrothermal & $203 @ 0.5 \mathrm{~A} / \mathrm{g}$ & $2 \mathrm{M} \mathrm{KOH}$ & $\begin{array}{l}91.1 \% \text { after } 10000 \\
\text { cycles@1.0 A/g }\end{array}$ & {$[28]$} \\
\hline $\mathrm{Mn}_{3}\left(\mathrm{PO}_{4}\right)_{2}$ & Hydrothermal & $149 @ 0.5 \mathrm{~A} / \mathrm{g}$ & $1 \mathrm{M} \mathrm{Na}_{2} \mathrm{SO}_{4}$ & $\begin{array}{l}88.9 \% \text { after } 10000 \\
\text { cycles@1.0 A/g }\end{array}$ & [28] \\
\hline $\mathrm{BiPO}_{4}$ & Microwave & $104 @ 1.0 \mathrm{~A} / \mathrm{g}$ & $2 \mathrm{M} \mathrm{KOH}$ & $\begin{array}{c}92 \% \text { after } 500 @ 1.0 \\
\mathrm{~A} / \mathrm{g}\end{array}$ & [39] \\
\hline $\mathrm{Mn}_{3}\left(\mathrm{PO}_{4}\right)_{2} / 100 \mathrm{mg} \mathrm{GF}$ & Hydrothermal & $270 @ 0.5 \mathrm{~A} / \mathrm{g}$ & $6 \mathrm{M} \mathrm{KOH}$ & $\begin{array}{c}99 \% \text { after } 1000 \\
\text { cycles@ } 9.0 \mathrm{~A} / \mathrm{g}\end{array}$ & $\begin{array}{l}\text { This } \\
\text { work }\end{array}$ \\
\hline
\end{tabular}

The electrochemical performance of the $\mathrm{Mn}_{3}\left(\mathrm{PO}_{4}\right)_{2} / 100 \mathrm{mg}$ GF composite was further evaluated in a two-electrode asymmetric cell device since $\mathrm{Mn}_{3}\left(\mathrm{PO}_{4}\right)_{2} / 100 \mathrm{mg}$ GF composite electrode has the highest specific capacitance. In the fabrication of asymmetric cell, 
$\mathrm{Mn}_{3}\left(\mathrm{PO}_{4}\right)_{2} / 100 \mathrm{mg}$ composite was used as a positive electrode and $\mathrm{AC}$ as a negative electrode. Due to the difference in the specific capacitance and charge-discharge time of both positive and negative electrodes in the asymmetric cell the charge balance $(q+=q-)$ was achieved, where $q+$ and $q$ - are charge stored in both positive and negative electrodes respectively. The mass balance between the positive and negative electrode is expressed as [40]:

$$
\frac{m_{+}}{m_{-}}=\frac{C_{\mathrm{S}(-)} \times V_{-}}{C_{\mathrm{S}(+)} \times V_{+}},
$$

where $C_{\mathrm{S}(+)}$ and $C_{\mathrm{S}(-)}$ are the specific capacitance of the active materials in positive and negative electrodes respectively, $m_{+}$and $m_{-}$are the masses of the active materials in positive and negative electrodes and $V_{+}$and $V_{-}$are the potential window of the positive and negative electrodes respectively. The mass ratio $\left(m_{+}: m_{-}\right)$of the positive to the negative electrodes of the cell was calculated as 3.4:2.0.

Figure 10(a) shows the $\mathrm{CV}$ curves of the $\mathrm{AC}$ electrode at different scan rates in a potential window range of -0.8 to $0.0 \mathrm{~V}$ which depicts a typical EDLC behavior of the electrode. In contrary to $\mathrm{AC}$, the $\mathrm{CV}$ curves of $\mathrm{Mn}_{3}\left(\mathrm{PO}_{4}\right)_{2} / 100 \mathrm{mg}$ GF electrode in a potential window range of 0.0 to $0.4 \mathrm{~V}$ showed a faradic behavior (Figure 6(b)). Figure 10(b) shows the CD curves of the AC electrode at different current densities in the range of 0.5 to $5.0 \mathrm{~A} \mathrm{~g}^{-1}$. These $\mathrm{CD}$ curves are nearly linear suggesting that the electrode has predominantly EDLC behavior in agreement with the $\mathrm{CV}$ curves. Now, since the AC electrode was evaluated in a potential window range of -0.8 to $0.0 \mathrm{~V}$ and the $\mathrm{Mn}_{3}\left(\mathrm{PO}_{4}\right)_{2} / 100 \mathrm{mg} \mathrm{GF}$ electrode in a range of 0.0 to $0.4 \mathrm{~V}$ as demonstrated in figure 10 (c) for a scan rate of $50 \mathrm{~m} \mathrm{Vs}^{-1}$, the $\mathrm{CV}$ curves of the $\mathrm{AC} / / \mathrm{Mn}_{3}\left(\mathrm{PO}_{4}\right)_{2} / 100 \mathrm{mg}$ GF asymmetric cell was able to reach a potential window range of 0.0 to $1.4 \mathrm{~V}$ (Figure $10(\mathrm{~d})$ ). These $\mathrm{CV}$ curves show that as potential approaches $0.0 \mathrm{~V}$ and 1.4 $\mathrm{V}$ the cathodic and anodic current does not show an increase which would be due to dihydrogen and oxygen evolution respectively, as it will be observed when a cell has exceeded its operating potential window. The wider potential window $(1.4 \mathrm{~V})$ of $\mathrm{AC} / / \mathrm{Mn}_{3}\left(\mathrm{PO}_{4}\right)_{2} / 100 \mathrm{mg}$ GF cell could be due to the phosphate content in the cell anode [37]. Figure 10(d) does not show obvious redox peaks as observed in figure 6(b) for $\mathrm{Mn}_{3}\left(\mathrm{PO}_{4}\right)_{2} / 100 \mathrm{mg}$ GF in three electrode measurements suggesting a good capacitive performance of the electrode. In addition, the CD curves of the asymmetric cell at various 
current densities display a linear behavior as shown in figure 10(e) hence depicting mostly EDLC behavior.
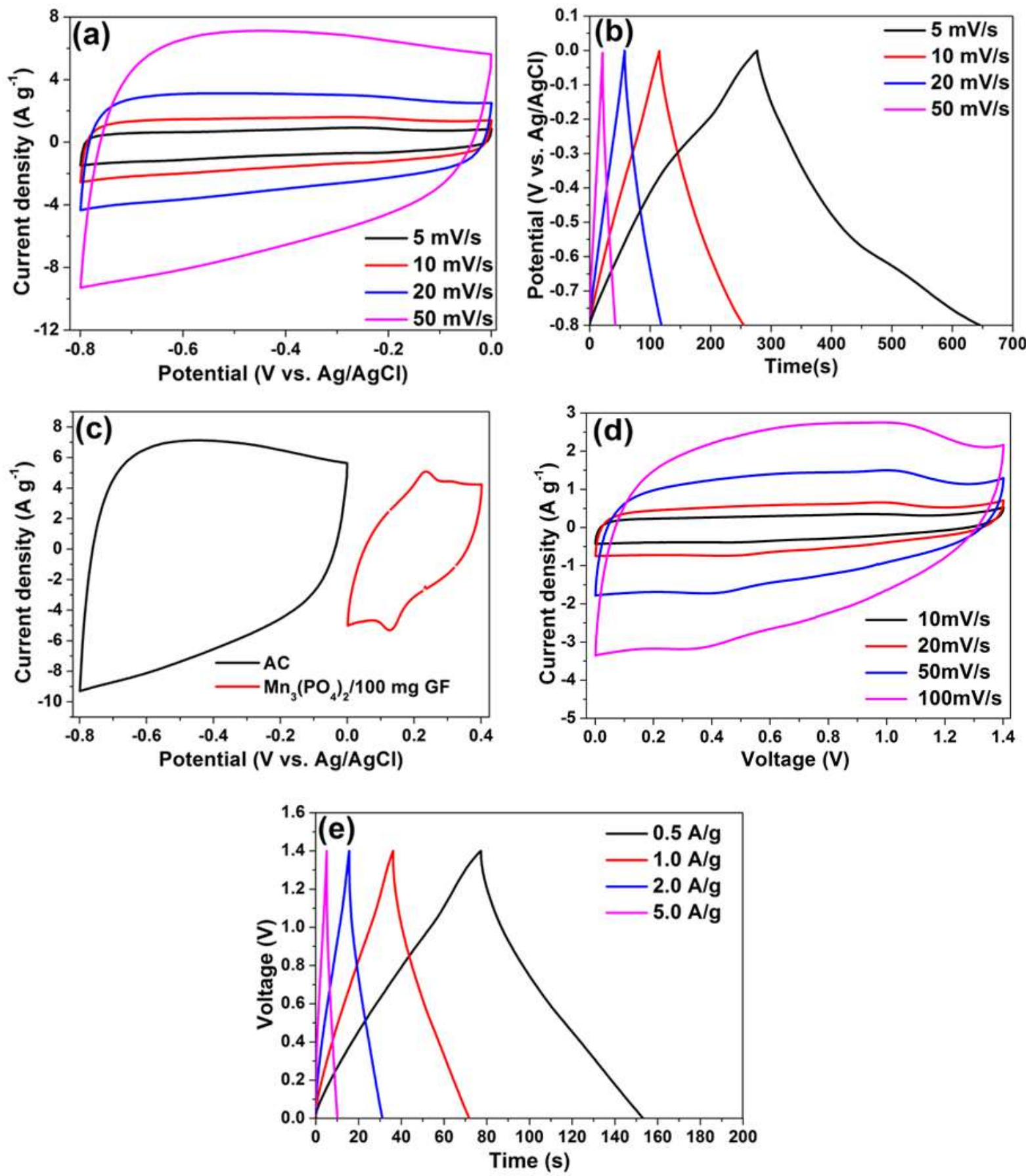

Figure 10. (a) $\mathrm{CV}$ curves of the $\mathrm{AC}$ electrode at different scan rates in a potential window range of -0.8 to 0.0 $\mathrm{V}$. (b) $\mathrm{CD}$ curves of the $\mathrm{AC}$ electrode at different current densities in the range of 0.5 to $5.0 \mathrm{~A} \mathrm{~g}^{-1}$. (c) $\mathrm{CV}$ curves of the $\mathrm{Mn}_{3}\left(\mathrm{PO}_{4}\right)_{2} / 100 \mathrm{mg} \mathrm{GF}$ and $\mathrm{AC}$ at a scan rate of $50 \mathrm{mV} \mathrm{s}^{-1}$. (d) $\mathrm{CV}$ curves of the $\mathrm{AC} / / \mathrm{Mn}_{3}\left(\mathrm{PO}_{4}\right)_{2} / 100 \mathrm{mg} \mathrm{GF}$ asymmetric cell device at scan rates of 10 to $100 \mathrm{mV} \mathrm{s}^{-1}$, and (e) $\mathrm{CD}$ curves of the cell device at current densities of 0.5 to $5 \mathrm{~A} \mathrm{~g}^{-1}$. 
Figure 11(a) shows the specific capacitance as a function of current density for the $\mathrm{AC} / / \mathrm{Mn}_{3}\left(\mathrm{PO}_{4}\right)_{2} / 100 \mathrm{mg}$ GF asymmetric cell device where the specific capacitance was calculated using equation 2 which is adopted for EDLC material since the device shows predominantly EDLC behavior. The asymmetric cell device yields specific capacitance of 28 , 26, 20 and $18 \mathrm{~F} \mathrm{~g}^{-1}$ at the current densities of $0.5,1.0,2.0$ and $5.0 \mathrm{~A} \mathrm{~g}^{-1}$ respectively. The cyclic performance of the asymmetric cell device was measured over 10000 continuous cycles at a current density of $2 \mathrm{~A} \mathrm{~g}^{-1}$ as shown in figure 11(b) (the inset to the figure shows the corresponding few cycles of the charge-discharge curves). As much as the device was giving low specific capacitance, the capacitance retention calculated for every 500 cycles of 10000 cycles, showed $96 \%$ capacitance retention indicating long-term electrochemical stability suggesting no significant change occurred in the structure of the electrode material during a cyclic lifetime. This cyclic performance is much higher than that found in previously published reports (Figure 11(c)) for the metal phosphate/oxide based composites evaluated in two-electrode cell device $[28,35,41,42]$. The excellent cyclic performance of $\mathrm{AC} / / \mathrm{Mn}_{3}\left(\mathrm{PO}_{4}\right)_{2} / 100 \mathrm{mg} \mathrm{GF}$ is due to the nature of the $\mathrm{Mn}_{3}\left(\mathrm{PO}_{4}\right)_{2}$ structure in $\mathrm{Mn}_{3}\left(\mathrm{PO}_{4}\right)_{2} / 100 \mathrm{mg}$ GF composite electrode which is very stable as a result of a strong P-O covalent bonds which share an edge involving two strong oxygen atom bonds with the Mn. 

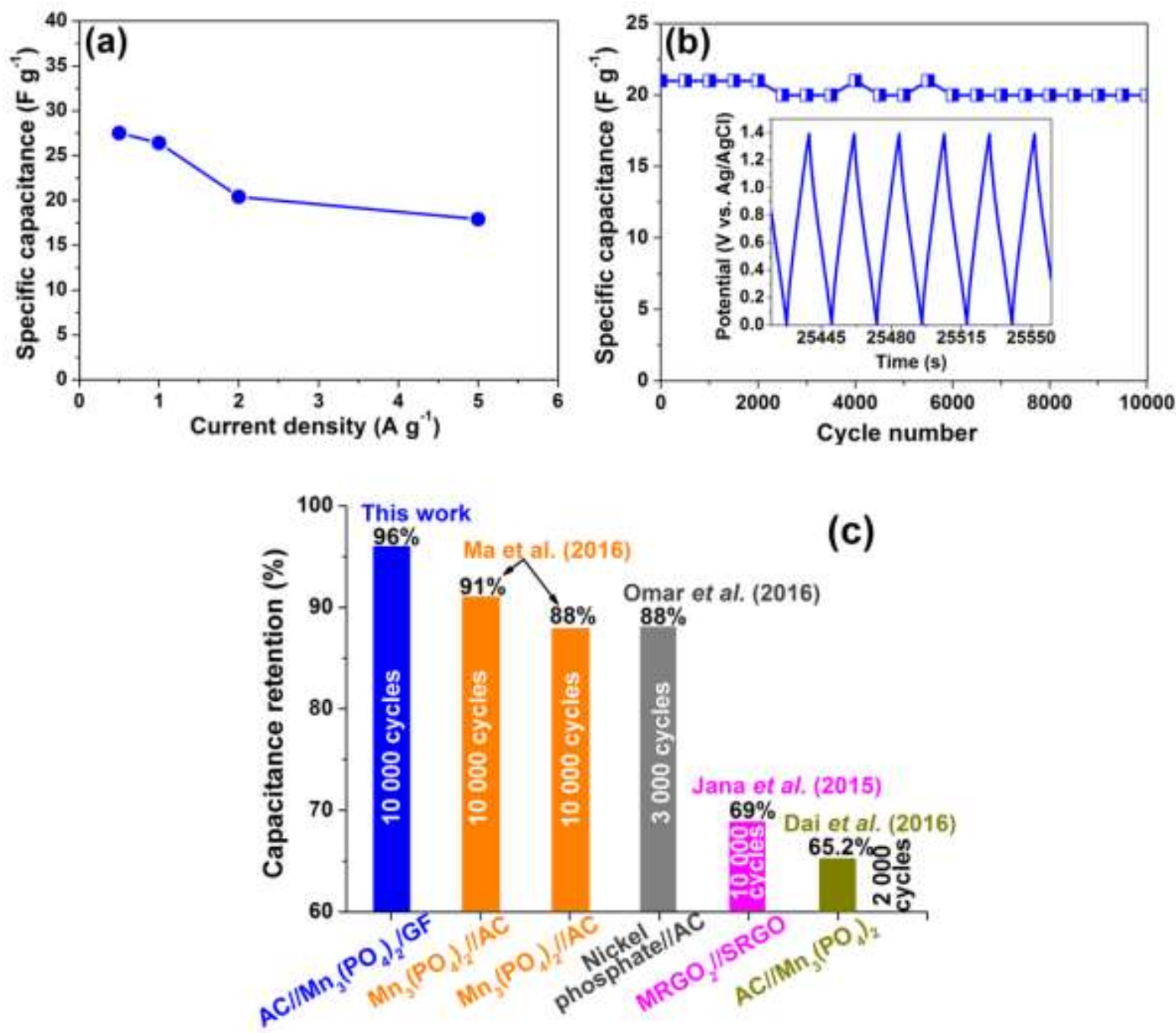

Figure 11. (a) The specific capacitance as a function of current density for the $\mathrm{AC} / / \mathrm{Mn}_{3}\left(\mathrm{PO}_{4}\right)_{2} / 100 \mathrm{mg} \mathrm{GF}$ asymmetric cell device. (b) The cyclic performance of the asymmetric cell device at a current density of $2 \mathrm{~A} \mathrm{~g}^{-1}$. (c) A comparison of capacitance retention found in this work and previously published reports.

Furthermore, the energy density and power density of the device were calculated as shown in figure 12(a) using the following equations:

$$
\begin{aligned}
& E_{\mathrm{d}}=\frac{1}{2} C V^{2} \\
& P_{\mathrm{d}}=\frac{E}{t}
\end{aligned}
$$

where $E_{\mathrm{d}}\left(\mathrm{Wh} \mathrm{kg}^{-1}\right)$ and $P_{\mathrm{d}}\left(\mathrm{W} \mathrm{kg}^{-1}\right)$ are the total energy and power densities respectively, $C_{\mathrm{S}}$ is the specific capacitance of the device $\left(\mathrm{F} \mathrm{g}^{-1}\right), V$ is the potential window $(V)$, and $t$ is the discharge time $(s)$. 
The calculated energy density values are 7.6, 7.1, 5.4 and $4.9 \mathrm{Wh} \mathrm{kg}^{-1}$, with corresponding the power density values of $360,710,1215$ and $3528 \mathrm{~W} \mathrm{~kg}^{-1}$, for current density ranging from 0.5 to $5 \mathrm{~A} \mathrm{~g}^{-1}$. These values are in the same order of magnitude as those found in previously published reports (Figure 12(a)) for phosphate-based composites evaluated in two-electrode cell device [28,37].

The EIS analysis of the $\mathrm{AC} / / \mathrm{Mn}_{3}\left(\mathrm{PO}_{4}\right)_{2} / 100 \mathrm{mg}$ GF asymmetric cell device was carried out as shown in figure 12(b) to evaluate the ion transport (diffusion) behavior in the cell. The EIS curve shows nearly a semi-circular arc in the high-frequency region and a linear relation close to being parallel to the $\mathrm{y}$-axis in the low-frequency region, indicating capacitive behavior. A representative circuit diagram for the device is presented in Figure 12 (c) which was used for fitting the EIS data (solid-lines in figure 12 (b)). The circuit diagram presents the resistance $\left(R_{\mathrm{S}}\right)$ in series with the charge transfer resistance $\left(R_{\mathrm{CT}}\right)$ at the high-frequency region and the Warburg $(W)$ which is in parallel with the real capacitance $\left(Q_{1}\right)$ [43] [44]. In addition, at the low frequency, a vertical line parallel to the imaginary axis with a mass capacitance denoted as $\left(Q_{2}\right)$ is observed. The deviation from this ideal behavior is attributed to a leakage resistance $\left(R_{\mathrm{L}}\right)$ due to the Faradaic charge transfer process, and this is always in parallel to the $Q_{2}$ as shown in the equivalent circuit. The values of $R_{\mathrm{S}}(2.7 \Omega)$ and $R_{\mathrm{CT}}(0.45 \Omega)$ obtained from the fitting are comparable to the experimental values $\left(R_{\mathrm{S}}=2.7 \Omega\right.$ and $\left.R_{\mathrm{CT}}=0.37 \Omega\right)$ indicating a good fit for the Nyquist plot. In brief, the $R_{\mathrm{CT}}$ describes the rate of reactions at the electrolyte-electrode interface $[45,46]$. This small $R_{\mathrm{CT}}$ value $(0.45 \Omega)$ confirms the chargetransfer kinetics and fast ion transport which is ideal for good capacitive performance, and $R_{\mathrm{S}}$ value $(2.7 \Omega)$ represents the ohmic resistance of the electrode material and the electrolyte. The phase angle as a function of frequency is presented in figure 12(c) showing the phase angle value of about $-81^{\circ}$ which is close to the ideal value of $-90^{\circ}$ suggesting that the $\mathrm{AC} / / \mathrm{Mn}_{3}\left(\mathrm{PO}_{4}\right)_{2} / 100 \mathrm{mg}$ GF cell approximate the ideal capacitive behavior. 

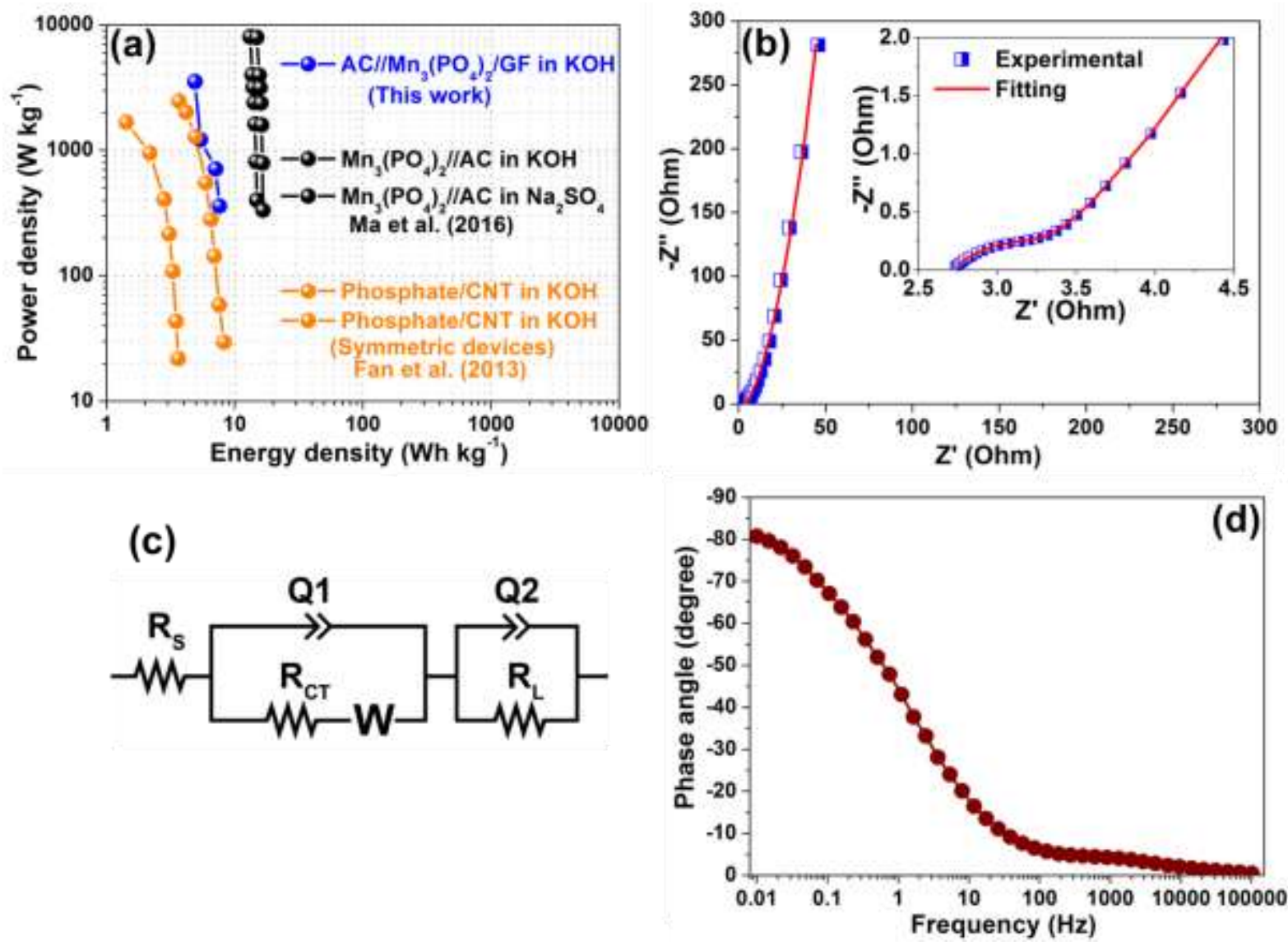

Figure 12. (a) Ragone plot of the $\mathrm{AC} / / \mathrm{Mn}_{3}\left(\mathrm{PO}_{4}\right)_{2} / 100 \mathrm{mg} \mathrm{GF}$ and phosphate-based composites found in previously published reports. (b) The Nyquist plot and (c) the equivalent circuit used for fitting the EIS data in (b) as shown by solid lines. (e) The phase angle as a function of frequency for $\mathrm{AC} / \mathrm{Mn}_{3}\left(\mathrm{PO}_{4}\right)_{2} / 100 \mathrm{mg} \mathrm{GF}$ asymmetric cell device.

\section{CONCLUSIONS}

In this work, a facile hydrothermal approach was used to synthesise $\mathrm{Mn}_{3}\left(\mathrm{PO}_{4}\right)_{2}$ hexagonal micro-rods using manganese acetate $\left(\mathrm{C}_{4} \mathrm{H}_{6} \mathrm{MnO}_{4}\right)$ and ammonium phosphate $\left(\mathrm{N}_{2} \mathrm{H}_{9} \mathrm{PO}_{4}\right)$ as precursors. $\mathrm{Mn}_{3}\left(\mathrm{PO}_{4}\right)_{2} / \mathrm{GF}$ composites with different GF mass loading were also synthesized by a hydrothermal process to improve the electrochemical performance of the $\mathrm{Mn}_{3}\left(\mathrm{PO}_{4}\right)_{2}$ micro-rods. The characterization of the as-prepared $\mathrm{Mn}_{3}\left(\mathrm{PO}_{4}\right)_{2}$ and $\mathrm{Mn}_{3}\left(\mathrm{PO}_{4}\right)_{2} / \mathrm{GF}$ composites by XRD, Raman spectroscopy, SEM, HRTEM and EDS proved the successful synthesis of $\mathrm{Mn}_{3}\left(\mathrm{PO}_{4}\right)_{2}$ hexagonal micro-rods and $\mathrm{Mn}_{3}\left(\mathrm{PO}_{4}\right)_{2} / \mathrm{GF}$ composites. The specific capacitance of the $\mathrm{Mn}_{3}\left(\mathrm{PO}_{4}\right)_{2} / \mathrm{GF}$ composite was observed to increase with GF mass loading up to $100 \mathrm{mg}$ before decreasing. The specific capacitance of $\mathrm{Mn}_{3}\left(\mathrm{PO}_{4}\right)_{2}$ electrode was obtained as $41 \mathrm{~F} \mathrm{~g}^{-1}$ and that of $\mathrm{Mn}_{3}\left(\mathrm{PO}_{4}\right)_{2} / 100 \mathrm{mg} \mathrm{GF}$ electrode as $270 \mathrm{~F} \mathrm{~g}^{-1}$ at a current 
density of $0.5 \mathrm{~A} \mathrm{~g}^{-1}$. The excellent capacitive performance of $\mathrm{Mn}_{3}\left(\mathrm{PO}_{4}\right)_{2} / 100 \mathrm{mg} \mathrm{GF}$ electrode could be attributed to the synergetic effect of the GF and the Faradic contribution of $\mathrm{Mn}_{3}\left(\mathrm{PO}_{4}\right)_{2}$ which improves the electrochemical performance of the electrode. Our results show improved specific capacitance of $\mathrm{Mn}_{3}\left(\mathrm{PO}_{4}\right)_{2} / 100 \mathrm{mg}$ GF composite electrode compared with the specific capacitance values for manganese phosphate based electrodes published previously by other studies. The asymmetric device showed a wide potential window of 0.0 to1.4 V, and also exhibited an excellent long-term cycle life. The device retained $96 \%$ of its initial specific capacitance over 10000 cycles at a current density of $2 \mathrm{~A} \mathrm{~g}^{-1}$, showing highly promising electrode material for electrochemical supercapacitor applications. This study is underway to further test the electrochemical performance of the $\mathrm{Mn}_{3}\left(\mathrm{PO}_{4}\right)_{2}$ micro-rods and $\mathrm{Mn}_{3}\left(\mathrm{PO}_{4}\right)_{2} / \mathrm{GF}$ composites as working electrodes in batteries.

\section{ACKNOWLEDGEMENTS}

This work is based on research supported by the South African Research Chairs Initiative (SARChI) of the Department of Science and Technology and the National Research Foundation (NRF) of South Africa (Grant No. 61056). Any opinion, finding and conclusion or recommendation expressed in this material is that of the author(s) and the NRF does not accept any liability in this regard. Abdulmajid A. Mirghni acknowledges the financial support from University of Pretoria and NRF through SARChI in Carbon Technology and Materials.

\section{REFERENCES}

[1] L. Long, W. Fu, M. Yan, Y. Yao, H. Wang, M. Wang, et al., A high-performance asymmetric supercapacitor based on a directly grown nickel bicarbonate/nickel foam composite, Electrochim. Acta. 180 (2015) 330-338.

doi:10.1016/j.electacta.2015.08.129.

[2] T.M. Masikhwa, M.J. Madito, D.Y. Momodu, RSC Advances High performance asymmetric supercapacitor based on CoAl-LDH / GF and activated carbon from, RSC Adv. 6 (2016) 46723-46732. doi:10.1039/C6RA07419G.

[3] M.Y. Ho, P.S. Khiew, D. Isa, T.K. Tan, W.S. Chiu, C.H. Chia, Charge storage performance of lithiated iron phosphate/activated carbon composite as symmetrical 
electrode for electrochemical capacitor, Curr. Appl. Phys. 14 (2014) 1564-1575. doi:10.1016/j.cap.2014.09.001.

[4] J. Yan, Z. Fan, T. Wei, W. Qian, M. Zhang, F. Wei, Fast and reversible surface redox reaction of graphene- $\mathrm{MnO} 2$ composites as supercapacitor electrodes, Carbon. 48 (2010) 3825-3833. doi:10.1016/j.carbon.2010.06.047.

[5] P. Simon, Y. Gogotsi, Materials for electrochemical capacitors, Nat. Mater. 7 (2008) $845-854$.

[6] Y. Yang, S. Lee, D.E. Brown, H. Zhao, X. Li, D. Jiang, et al., Fabrication of ultrafine manganese oxide-decorated carbon nanofibers for high-performance electrochemical capacitors, Electrochim. Acta. 211 (2016) 524-532.

doi:10.1016/j.electacta.2016.06.012.

[7] H.B. Li, M.H. Yu, F.X. Wang, P. Liu, Y. Liang, J. Xiao, et al., Amorphous nickel hydroxide nanospheres with ultrahigh capacitance and energy density as electrochemical pseudocapacitor materials., Nat. Commun. 4 (2013) 1894. doi:10.1038/ncomms2932.

[8] V. Subramanian, H. Zhu, R. Vajtai, P.M. Ajayan, B. Wei, Hydrothermal synthesis and pseudocapacitance properties of MnO 2 nanostructures, J. Phys. Chem. B. 109 (2005) 20207-20214. doi:10.1021/jp0543330.

[9] M. Liu, L. Gan, W. Xiong, Z. Xu, D. Zhu, L. Chen, Development of MnO2/porous carbon microspheres with a partially graphitic structure for high performance supercapacitor electrodes, J. Mater. Chem. A. 2 (2014) 2555. doi:10.1039/c3ta14445c.

[10] H.M. Jeong, K.M. Choi, T. Cheng, D.K. Lee, R.J. Zhou, I.W. Ock, et al., Rescaling of metal oxide nanocrystals for energy storage having high capacitance and energy density with robust cycle life, Proc. Natl. Acad. Sci. U. S. A. 112 (2015) 7914-7919. doi:10.1073/pnas.1503546112.

[11] M. Zhi, C. Xiang, J. Li, M. Li, N. Wu, Nanostructured carbon-metal oxide composite electrodes for supercapacitors: a review., Nanoscale. 5 (2013) 72-88. doi:10.1039/c2nr32040a.

[12] R.B. Rakhi, W. Chen, D. Cha, H.N. Alshareef, Substrate dependent self-organization of mesoporous cobalt oxide nanowires with remarkable pseudocapacitance, Nano Lett. 
12 (2012) 2559-2567. doi:10.1021/nl300779a.

[13] L. Huang, D. Chen, Y. Ding, S. Feng, Z.L. Wang, M. Liu, Nickel - Cobalt Hydroxide Nanosheets Coated on NiCo 2 O 4 Nanowires Grown on Carbon Fiber Paper for HighPerformance Pseudocapacitors, ACS Appl. Mater. Interfaces. 5 (2013) 11159-11162. doi:10.1021/nl401086t.

[14] C. Xiang, M. Li, M. Zhi, A. Manivannan, N. Wu, A reduced graphene oxide/Co3O4 composite for supercapacitor electrode, J. Power Sources. 226 (2013) 65-70. doi:10.1016/j.jpowsour.2012.10.064.

[15] Z.K. Ghouri, M. Shaheer Akhtar, A. Zahoor, N.A.M. Barakat, W. Han, M. Park, et al., High-efficiency super capacitors based on hetero-structured ??-MnO $<\mathrm{inf}>2</ \mathrm{inf}>$ nanorods, J. Alloys Compd. 642 (2015) 210-215. doi:10.1016/j.jallcom.2015.04.082.

[16] X. Su, L. Yu, G. Cheng, H. Zhang, M. Sun, X. Zhang, High-performance $\alpha-$ $\mathrm{MnO}<$ inf $>2</$ inf $>$ nanowire electrode for supercapacitors, Appl. Energy. 153 (2015) 94-100. doi:10.1016/j.apenergy.2014.07.094.

[17] M. Song, S. Cheng, H. Chen, W. Qin, K. Nam, S. Xu, et al., Anomalous Pseudocapacitive Behavior of a Nanostructured, Mixed- Valent Manganese Oxide Film for Electrical Energy Storage, Nano Lett. 12 (2012) 3483-3490.

[18] N. Dalili, M.P. Clark, E. Davari, D.G. Ivey, Microstructural characterization of the cycling behavior of electrodeposited manganese oxide supercapacitors using 3D electron tomography, J. Power Sources. 328 (2016) 318-328. doi:10.1016/j.jpowsour.2016.08.012.

[19] S.B. Yoon, K.B. Kim, Effect of poly(3,4-ethylenedioxythiophene) (PEDOT) on the pseudocapacitive properties of manganese oxide $(\mathrm{MnO} 2)$ in the PEDOT/MnO 2/multiwall carbon nanotube (MWNT) composite, Electrochim. Acta. 106 (2013) 135142. doi:10.1016/j.electacta.2013.05.058.

[20] C.C. Chen, C.Y. Yang, C.K. Lin, Improved pseudo-capacitive performance of manganese oxide films synthesized by the facile sol-gel method with iron acetate addition, Ceram. Int. 39 (2013) 7831-7838. doi:10.1016/j.ceramint.2013.03.043.

[21] A. Bahloul, B. Nessark, E. Briot, H. Groult, A. Mauger, K. Zaghib, et al., Polypyrrolecovered $\mathrm{MnO} 2$ as electrode material for supercapacitor, J. Power Sources. 240 (2013) 
267-272. doi:10.1016/j.jpowsour.2013.04.013.

[22] C. Chen, W. Chen, J. Lu, D. Chu, Z. Huo, Q. Peng, et al., Transition-metal phosphate colloidal spheres, Angew. Chemie - Int. Ed. 48 (2009) 4816-4819. doi:10.1002/anie.200900639.

[23] M. Gong, Z. Niu, Q. Peng, Y. Li, Copper-mediated synthesis of PdI2 colloidal spheres, Sci. China Chem. 54 (2011) 1027-1031. doi:10.1007/s11426-011-4297-8.

[24] I. V Cadmium-, L.L. Springsteen, E. Matijevi, Colloid Science Preparation and properties of uniform colloidal metal phosphates '• E, 1015 (1989) 1007-1015.

[25] Y. Chang, N.-E. Shi, S. Zhao, D. Xu, C. Liu, Y.-J. Tang, et al., Coralloid $\mathrm{Co}_{2} \mathrm{P}_{2} \mathrm{O}_{7}$ Nanocrystals Encapsulated by Thin Carbon Shells for Enhanced Electrochemical Water Oxidation, ACS Appl. Mater. Interfaces. (2016) acsami.6b07209. doi:10.1021/acsami.6b07209.

[26] H. Pang, S. Wang, W. Shao, S. Zhao, B. Yan, X. Li, et al., Few-layered CoHPO4.3H2O ultrathin nanosheets for high performance of electrode materials for supercapacitors, Nanoscale. 5 (2013) 5752-5757. doi:10.1039/c3nr01460f.

[27] W. Massa, O. V. Yakubovich, O. V. Dimitrova, A novel modification of manganese orthophosphate Mn3(PO 4)2, Solid State Sci. 7 (2005) 950-956. doi:10.1016/j.solidstatesciences.2005.03.005.

[28] X.-J. Ma, W.-B. Zhang, L.-B. Kong, Y.-C. Luo, L. Kang, Electrochemical performance in alkaline and neutral electrolytes of a manganese phosphate material possessing a broad potential window, RSC Adv. 6 (2016) 40077-40085. doi:10.1039/C6RA02217K.

[29] C. Zhong, Y. Deng, W. Hu, J. Qiao, L. Zhang, J. Zhang, A review of electrolyte materials and compositions for electrochemical supercapacitors., Chem. Soc. Rev. 44 (2015) 7484-7539. doi:10.1039/c5cs00303b.

[30] F. Barzegar, A.A. Khaleed, F.U. Ugbo, K.O. Oyeniran, D.Y. Momodu, A. Bello, et al., Cycling and floating performance of symmetric supercapacitor derived from coconut shell biomass, AIP Adv. 6 (2016) 115306. doi:10.1063/1.4967348.

[31] J.S. Stephens, C. Calvo, Crystal structure of $\beta^{\prime} \mathrm{Mn}_{3}\left(\mathrm{PO}_{4}\right)_{2}$, Can. J. Chem. 47 (1969) 2215-2225. doi:10.1139/v69-360. 
[32] M.B. Sahana, S. Vasu, N. Sasikala, S. Anandan, H. Sepehri-Amin, C. Sudakar, et al., Raman spectral signature of Mn-rich nanoscale phase segregations in carbon free LiFe 1 Àx Mn x PO 4 prepared by hydrothermal technique, (n.d.). doi:10.1039/c4ra11102h.

[33] B. Akinwolemiwa, C. Peng, G.Z. Chen, Redox electrolytes in supercapacitors, J. Electrochem. Soc. 162 (2015) A5054-A5059. doi:10.1149/2.0111505jes.

[34] A. Laheäär, P. Przygocki, Q. Abbas, F. Béguin, Appropriate methods for evaluating the efficiency and capacitive behavior of different types of supercapacitors, 2015. doi:10.1016/j.elecom.2015.07.022.

[35] M. Jana, J.S. Kumar, P. Khanra, P. Samanta, H. Koo, N.C. Murmu, et al., Superior performance of asymmetric supercapacitor based on reduced graphene oxide-manganese carbonate as positive and sono-chemically reduced graphene oxide as negative electrode materials, J. Power Sources. 303 (2016) 222-233.

[36] G. Godillot, L. Guerlou-Demourgues, P.-L. Taberna, P. Simon, C. Delmas, Original Conductive Nano-Co3O4 Investigated as Electrode Material for Hybrid Supercapacitors, Electrochem. Solid-State Lett. 14 (2011) A139. doi:10.1149/1.3609259.

[37] X. Fan, C. Yu, Z. Ling, J. Yang, J. Qiu, Hydrothermal synthesis of phosphatefunctionalized carbon nanotube-containing carbon composites for supercapacitors with highly stable performance, ACS Appl. Mater. Interfaces. 5 (2013) 2104-2110. doi:10.1021/am303052n.

[38] M. Minakshi, D. Mitchell, R. Jones, F. Alenazey, T. Watcharatharapong, S. Chakraborty, et al., Synthesis, structural and electrochemical properties of sodium nickel phosphate for energy storage devices, Nanoscale. 8 (2016) 11291-11305. doi:10.1039/C6NR01179A.

[39] S. Vadivel, D. Maruthamani, M. Kumaravel, B. Saravanakumar, B. Paul, S.S. Dhar, et al., Supercapacitors studies on BiPO4 nanoparticles synthesized via a simple microwave approach, J. Taibah Univ. Sci. (2016) 2-7. doi:10.1016/j.jtusci.2016.09.007.

[40] T.M.. Masikhwa, M.J.. Madito, D.Y.. Momodu, J.K.. Dangbegnon, O.. Guellati, A.. Harat, et al., High performance asymmetric supercapacitor based on CoAl-LDH/GF 
and activated carbon from expanded graphite, RSC Adv. 6 (2016) 46723-46732. doi:10.1039/c6ra07419g.

[41] F.S. Omar, A. Numan, N. Duraisamy, S. Bashir, K. Ramesh, S. Ramesh, Ultrahigh capacitance of amorphous nickel phosphate for asymmetric supercapacitor applications, RSC Adv. 6 (2016) 76298-76306. doi:10.1039/C6RA15111F.

[42] Y.H. Dai, L. Bin Kong, K. Yan, M. Shi, Y.C. Luo, L. Kang, Facile fabrication of manganese phosphate nanosheets for supercapacitor applications, Ionics (Kiel). (2016) 1-9. doi:10.1007/s11581-016-1652-y.

[43] W. Sun, X. Chen, Preparation and characterization of polypyrrole films for threedimensional micro supercapacitor, 193 (2009) 924-929.

doi:10.1016/j.jpowsour.2009.04.063.

[44] H. Li, J. Wang, Q. Chu, Z. Wang, F. Zhang, S. Wang, Theoretical and experimental specific capacitance of polyaniline in sulfuric acid, 190 (2009) 578-586. doi:10.1016/j.jpowsour.2009.01.052.

[45] D.Y. Momodu, F. Barzegar, A. Bello, J. Dangbegnon, T. Masikhwa, J. Madito, et al., Simonkolleite-graphene foam composites and their superior electrochemical performance, Electrochim. Acta. 151 (2015) 591-598. doi:10.1016/j.electacta.2014.11.015.

[46] B. Wang, Q. Liu, Z. Qian, X. Zhang, J. Wang, Z. Li, et al., Two steps in situ structure fabrication of Ni-Al layered double hydroxide on Ni foam and its electrochemical performance for supercapacitors, J. Power Sources. 246 (2014) 747-753. doi:10.1016/j.jpowsour.2013.08.035. 